\title{
Redox-driven changes in porewater chemistry in the unsaturated zone of the chalk aquifer beneath unlined cattle slurry lagoons
}

\author{
D C Gooddy ${ }^{1 \dagger}$, W Clay $^{2 *}$ and S H Bottrell ${ }^{2}$
}

${ }^{1}$ British Geological Survey, Maclean Building, Wallingford Oxfordshire, OX10 8BB, UK

${ }^{2}$ School of Earth Sciences, University of Leeds, Leeds, LS2 9JT, UK

*Present address: WS Atkins Consultants Ltd., The Old Brewery, High Court, Leeds LS2 7ES, UK

${ }^{\dagger}$ Corresponding author: e-mail dcg@bgs.ac.uk

phone +44(0) 1491692328

fax $\quad+44(0) 1491692345$

\begin{abstract}
Farm waste stores such as cattle slurry lagoons are widespread in the UK and many overly important aquifers. Stores can be serious risks to water quality because they are important sources of nitrogen species, organic carbon and pathogenic microbes. At two sites on the Chalk aquifer of southern England, inclined boreholes were drilled and cored to obtain aquifer material from directly beneath unlined slurry stores. Vertical boreholes were also drilled adjacent to the slurry stores to determine any lateral movement of contaminants. Interstitial porewaters were analysed for major and minor ions and sulphur isotopes. At the second site, unsaturated zone gases were sampled from the inclined hole. Infiltration of slurry into the unsaturated zone caused significantly elevated concentrations of metals such as copper and nickel at both sites. Sulphate reduction was occurring at Site 1, as evidenced by sulphate concentrations decreasing from $150 \mathrm{mg} / \mathrm{L}$ to $50 \mathrm{mg} / \mathrm{L}$ and enhanced ratios of $\delta^{34} \mathrm{~S}^{-\mathrm{SO}_{4}}$ and $\delta^{18} \mathrm{O}_{-} \mathrm{SO}_{4}$. Ammonium-N also leaches along with dissolved organic carbon which were found $17 \mathrm{~m}$ below ground surface at concentrations up to $400 \mathrm{mg} / \mathrm{L}$ and $260 \mathrm{mg} / \mathrm{L}$ respectively. Contaminant concentrations were similar in the porewaters from both the inclined and vertical boreholes. At Site 2, higher contaminant concentrations were found in the inclined borehole compared with the vertical borehole. Organic carbon concentrations were considerably lower than at Site 1, ranging from 10$70 \mathrm{mg} / \mathrm{l}$. Ammonium-N concentrations reached a maximum concentration of $25 \mathrm{mg} / \mathrm{l}$, however nitrate- $\mathrm{N}$ concentrations were up to $500 \mathrm{mg} / \mathrm{L}$ and sulphate concentrations were generally higher than Site 1. Data for $\mathrm{N}_{2} / \mathrm{Ar}$ and $\delta^{15} \mathrm{~N}-\mathrm{N}_{2}$ from the gas samplers show a peak of 102 and 2.2\%o respectively at $14 \mathrm{~m}$ below ground level indicating denitrification was taking place. Evidence from $\delta^{34} \mathrm{~S}^{-\mathrm{SO}_{4}}$ and $\delta^{18} \mathrm{O}_{-} \mathrm{SO}_{4}$ suggest that some sulphate reduction was taking place simultaneously. From methane and ammonia detected at depth it is suggested that slurry contamination, emanating from early use of the store, has passed through the top $18 \mathrm{~m}$ of the unsaturated zone at Site 2. The presence of high concentrations of nitrate and lower concentrations of organic carbon suggests that this lagoon has formed a relatively impermeable seal at its base within the first few years of its lifetime. The anoxic conditions at both sites may have mobilised uranium from nitrogen-phosphate-potassium fertilisers. Both sites are continuing to impact on the porewater chemistry and pose a risk of groundwater contamination.
\end{abstract}

\section{INTRODUCTION}

Groundwater provides over 30\% of all water abstracted in England and Wales and accounts for more than $80 \%$ of the total public supply in south-east England. Both industry and agriculture rely on groundwater in many areas and it is the predominant source for private water supplies. The Chalk is 
the major United Kingdom (UK) aquifer and its groundwater flow regime is well documented (Price, 1987). The Chalk is a soft microporous fractured limestone and has three components of porosity and permeability: 1) the Chalk has high intergranular porosity (25-45\%) but only low intergranular permeability from pore-neck sizes of less than $1 \mu \mathrm{m}$ (Price et al., 1976); 2) joint components that have low porosity (0.1-1\%) but depending on frequency, can increase the hydraulic conductivity by two or three orders of magnitude; 3 ) fissures that result from the solution and enlargement of joints can account for the bulk of flow in the saturated zone.

Although storage of livestock manure can present a serious potential risk of surface water pollution, there has not been the same concern about potential pollution to groundwater possibly because of the greater dilution and less immediate impact expected in groundwater systems (Gooddy et al., 2001). The majority of livestock slurry storage structures generally only pose a risk of water pollution because of structural or operator failure. Only in the case of unlined earth-based slurry lagoons, which were unregulated before 1991, and field heaps of solid manure, is there risk that pollutants can leach to groundwater (Withers et al. 1998; Gooddy 2002). There are about 10,000 earth-based slurry lagoons constructed prior to 1991 in England and Wales (Nicholson \& Brewer 1997) many of which could be overlying aquifers.

There is conflicting evidence with regard to the risks from unlined cattle slurry lagoons (Kanazawa et al., 1999; Ritter and Chirnside, 1983). Monitoring around large-scale structures (Miller et al., 1984; Rowsell et al., 1985) in Canada has shown no adverse effects on groundwater, even when constructed on sandy material. The self-sealing effects of slurry at the lagoon base is believed to be the mechanism that protects the underlying unsaturated zone. Monitoring of slurry constituents in groundwater beneath lagoons in the United States has shown that the infiltration rate of lagoon contents decreases with time (Oliver et al., 1974; Robinson, 1973; Sewell et al. 1975; and Barrington et al., 1983), although there is little consensus as to the rate or degree of this decrease. In the UK, data from a single site on the Chalk of south-east England indicated that the organic-carbon-rich slurry and its constituents had leached from the bottom of recently decommissioned unlined slurry lagoon and contaminated an observation well sited $80 \mathrm{~m}$ down groundwater gradient (Gooddy et al. 1998; Withers et al., 1998). Similarly, a study from Japan (Kanazawa et al., 1999) showed evidence of groundwater pollution $75 \mathrm{~m}$ away from an unlined slurry lagoon just 4 days after the lagoon was first filled.

\subsection{Biochemical Redox Processes and Calcite Dissolution}

Decay of organic matter in cattle slurry occurs in the chalk matrix via aerobic and anaerobic respiration. The distinction between these processes is important in that they proceed along of decreasing energy efficiency with declining rates of organic matter decay.

Organic matter is primarily degraded by oxidation reactions (the removal of electrons) mediated by bacteria that derive energy in the process. During bacterially mediated oxidation, proteins in the slurry break down into their constituent amino acids, which contain both nitrogen and sulphur compounds. These compounds are ultimately broken down into inorganic species such as ammonia, nitrate, and sulphate and cations such as sodium and potassium. This form of oxidation is predominantly via dissimilative metabolism by chemoheterotrophic bacteria that can utilise a range of potential Terminal Electron Acceptors (TEAs) in the reaction. The range of TEA species are characterised by differences in their energy yield. Aerobic respiration is the most energy productive process and is followed by anaerobic respiration processes that yield successively less energy; the order of energy yield on reduction is $\mathrm{NO}_{3}{ }^{-}>\mathrm{Mn}^{4+}>\mathrm{Fe}^{3+}>\mathrm{SO}_{4}{ }^{2-}>\mathrm{CO}_{2}$. The reactants and products from these reactions are commonly used to define identifiable geochemical zones that can be used to identify the thermodynamic TEA progression (Lawrence et al., 2000).

Chalk in the UK contains more than $99 \% \mathrm{CaCO}_{3}$ (Murphy, 1998). The matrix content of redox sensitive elements such as $\mathrm{Fe}^{2+}$ and $\mathrm{Mn}^{4+}$ is very low, $(<0.05 \%)$ and therefore they are unlikely to participate in any redox related reactions. Reactions 1-4 demonstrate that in a calcium carbonate 
environment, redox reactions all result in the production of $\mathrm{HCO}_{3}{ }^{-}$and or $\mathrm{CO}_{2}$. The relative contribution of $\mathrm{HCO}_{3}{ }^{-}$or $\mathrm{CO}_{2}$ results from hydrogen ion concentration of the porewater and the interplay between aerobic and anaerobic respiration processes. In an aerobic environment calcite will be dissolved but in aerobic environments calcite is precipitated.

$\mathrm{CaCO}_{3}+2 \mathrm{H}^{+} \Leftrightarrow 2 \mathrm{HCO}_{3}^{-}+\mathrm{Ca}^{2+}$

Oxidation (aerobic respiration)

$\mathrm{CH}_{2} \mathrm{O}+\mathrm{O}_{2} \Rightarrow \mathrm{CO}_{2}+\mathrm{H}_{2} \mathrm{O}$

Bacterial Nitrate Reduction (denitrification)

$5 \mathrm{CH}_{2} \mathrm{O}+4 \mathrm{NO}_{3}^{-} \Rightarrow 2 \mathrm{~N}_{2}+4 \mathrm{HCO}_{3}^{-}+\mathrm{CO}_{2}+3 \mathrm{H}_{2} \mathrm{O}$

Bacterial Sulphate Reduction

$2 \mathrm{CH}_{2} \mathrm{O}+\mathrm{SO}_{4}^{--} \Rightarrow \mathrm{H}_{2} \mathrm{~S}+2 \mathrm{HCO}_{3}^{-}$

\subsection{Sulphate Stable Isotopes}

Stable isotopes help understand redox processes by elucidating both reduction and re-oxidation of TEA species. Re-oxidation of TEA cannot be determined by chemical data alone because only net reduction can be determined. The fractionation of ${ }^{18} \mathrm{O} /{ }^{16} \mathrm{O}$ and ${ }^{34} \mathrm{~S} /{ }^{32} \mathrm{~S}$ can be used to identify bacterial sulphate reduction (BSR) and subsequently re-oxidation of the reduction products. Sulphur is a useful isotopic indicator because it is present in cattle slurry and can exist in a wide range of oxidation states.

During BSR the light ${ }^{32} \mathrm{~S}$ isotope is preferentially metabolised due to its weaker bond strength, producing a kinetic isotopic fractionation (Nakai and Jensen 1964). As ${ }^{32} \mathrm{~S}$ reacts more quickly to form hydrogen sulphide there is an enrichment of ${ }^{34} \mathrm{~S}$ in the remaining sulphate. BSR also causes exchange of oxygen isotopes between sulphate and water, resulting in enrichment of ${ }^{18} \mathrm{O}$ in remaining sulphate (Fritz et al. 1989). Reoxidation of sulphide can form new sulphate with an oxygen isotopic composition distinct from that of the original sulphate and thus provide an isotopic tracer for this process.

\subsection{Determining denitrification in the unsaturated zone using $\mathrm{N}_{2} \mathrm{O}, \mathrm{N}$ isotopes and $\mathrm{N}_{2} / \mathrm{Ar}$}

Denitrification occurs under anaerobic conditions when nitrate is used as a TEA leading to the stepwise production of nitrogen with nitric oxide and nitrous oxide as gaseous intermediate products (5).

$\mathrm{NO}_{3}{ }^{-} \Rightarrow \mathrm{NO}_{2}{ }^{-} \Rightarrow \mathrm{NO} \Rightarrow \mathrm{N}_{2} \mathrm{O} \Rightarrow \mathrm{N}_{2}$

Detection of nitrous oxide should therefore be a good indicator that denitrification is taking place. However, nitrous oxide can also be produced under aerobic conditions as an intermediate product during the oxidation of ammonia in nitrification (6-8), therefore detection on its own cannot provide unequivocal evidence for denitrification.

$$
\begin{aligned}
& 2 \mathrm{NH}_{4}^{+}+2 \mathrm{O}_{2} \Rightarrow \mathrm{N}_{2} \mathrm{O}+2 \mathrm{H}^{+}+3 \mathrm{H}_{2} \mathrm{O} \\
& \mathrm{N}_{2} \mathrm{O}+1 / 2 \mathrm{O}_{2} \Rightarrow 2 \mathrm{NO}_{2}^{-} \\
& \mathrm{NO}_{2}^{-}+1 / 2 \mathrm{O}_{2} \Rightarrow \mathrm{NO}_{3}^{-}
\end{aligned}
$$

During denitrification, the nitrate that remains becomes progressively enriched in ${ }^{15} \mathrm{~N}$ because ${ }^{14} \mathrm{~N}$ is concentrated in the gas phase. Under closed conditions there is an exponential increase in $\delta^{15} \mathrm{~N}$ of the residual nitrate (Mariotti et al., 1988). Such behaviour provides positive evidence for denitrification but is rather insensitive until the majority of the nitrate has been denitrified. Other processes, such as volatilisation of ammonia, also result in the preferential loss of ${ }^{14} \mathrm{~N}$ and therefore ultimately in ${ }^{15} \mathrm{~N}$ rich residual nitrate-N.

Since the end product of denitrification is nitrogen gas, an obvious way of detecting denitrification is 
by measuring the evolved nitrogen. However, due to the very high atmospheric concentration measuring an excess of nitrogen is problematic. It is possible to correct for this problem by high precision measurement of $\mathrm{N}_{2} / \mathrm{Ar}$ ratios. In atmospheric air this ratio is fixed at 83.6 and any increase in nitrogen due to denitrification will increase in the ratio (Darling et al., 1997).

By combining these methods it should be possible to obtain unequivocal evidence for denitrification in the unsaturated zone even in an environment that contains very high concentrations of ammonia such as a farm waste store.

\section{SITE DESCRIPTIONS}

\subsection{Site 1}

Site 1 is situated about $5 \mathrm{~km}$ from Salisbury, Wiltshire, UK (exact location withheld for farmer confidentiality). Slurry is stored in a pit roughly $15 \mathrm{~m}$ long, $6 \mathrm{~m}$ wide and $2 \mathrm{~m}$ deep. The pit is flush to ground level and was constructed in 1978 (Figure 1).

The farm is situated on the Upper Chalk high above a river valley and so is missing any possible alluvium or gravel sequences. A borehole situated on the farm, drilled in 1973, provides water for the cattle and for washing the milking sheds. The log for this borehole states that the top 10 metres of drilling was into Pebble Beds. Drilling carried out in 1997 as part of the current study revealed pebbles occurred down as far as 7 metres below ground level ( $\mathrm{m} \mathrm{bgl)}$. The water table was measured at the farm borehole in 1973 as $44 \mathrm{~m}$ bgl. The farm has a herd of roughly 160 dairy cows.

\section{$2.2 \quad$ Site 2}

Site 2 is situated about $8 \mathrm{~km}$ from Salisbury, Wiltshire, UK (exact location withheld for farmer confidentiality). Slurry is stored in a pit roughly $20 \mathrm{~m}$ long, $8 \mathrm{~m}$ wide and $2.5 \mathrm{~m}$ deep. Solid and liquid wastes are disposed of together in the same lagoon. The lagoon is earth walled and constructed on a hill. It has been built up to counter the incline, reaching a height of roughly $4 \mathrm{~m}$ above ground level at its southerly end (Figure 2a). The lagoon was constructed in 1983.

The farm is situated on the boundary of the Middle and Upper Chalk in a river valley and so is overlain by alluvium and gravels. The lagoon however is on top of a hill and therefore free of the gravel layer. By extrapolation between boreholes at the top and bottom of the hill, the water table is estimated to be between 35 and $40 \mathrm{~m}$ bgl. The farm has a herd of roughly 200 dairy cows

\section{METHODS}

\subsection{Borehole Construction}

As the slurry stores were still active, it was necessary to construct inclined boreholes (at an angle of $45^{\circ}$ ) so as to obtain chalk core from directly underneath the lagoon. Continuous core was obtained throughout the unsaturated zone by rotary coring. In addition to the inclined holes, vertical holes were drilled adjacent to the lagoons to identify whether or not there was any lateral movement of slurry components. The inclined holes were drilled to a depth below ground level of 17 metres and 18.4 metres respectively for Sites 1 and 2. The vertical holes were both drilled to a depth of $15 \mathrm{~m} \mathrm{bgl}$. Boreholes at Site 1 were constructed at the opposite end of the lagoon to the farm sheds where the herd is housed and milked. The inclined borehole at Site 2 was angled so as to sample from beneath the entire width of the slurry lagoon. After construction of the inclined hole at Site 2, 6 specially designed gas samplers were installed at discrete depths throughout (see 3.4). Boreholes were only drilled in the unsaturated zone to avoid direct contamination of the saturated zone from the slurry lagoons. 


\subsection{Unsaturated Zone Porewater Extraction and Chemical Analysis}

Porewater was extracted from the cored material by the high speed centrifuge 'drainage' method (Edmunds and Bath, 1976). Briefly, core crushed in a polythene bag to fragments of roughly $5 \mathrm{~mm}$ diameter are placed into the buckets of a fixed angle rotor refrigerated centrifuge. Delrin liners with collection cups and pre-filters hold the rock fragments in the centrifuge rotor. The samples are centrifuged at $14000 \mathrm{rpm}$ for 35 minutes. The supernatant porewater is then split into three fractions; one filtered and acidified for cations; a second filtered and unacidified for anions; and a third unfiltered and unacidified for dissolved organic carbon. Typically a minimum of $30 \mathrm{ml}$ of extracted porewater was required to carry out all the chemical measurements required.

Filtered acidified porewaters are analysed using an ARL 34000C Inductively Coupled Plasma-Optical Emission Spectrometer (ICP-OES) which is calibrated for the following 16 elements: $\mathrm{Na}, \mathrm{K}, \mathrm{Ca}, \mathrm{Mg}$, $\mathrm{B}, \mathrm{Ba}, \mathrm{Li}, \mathrm{P}_{\text {total, }}, \mathrm{SO}_{4}, \mathrm{Si}, \mathrm{Sr}, \mathrm{Be}, \mathrm{Ba}, \mathrm{Y}, \mathrm{Fe}_{\text {total }}$ and $\mathrm{Al}$. All analyses are blank corrected and detection limits defined as 6 times the standard deviation of the blank.

Filtered acidified samples from each borehole were also analysed for $\mathrm{Mn}, \mathrm{Mo}, \mathrm{Cr}, \mathrm{Co}, \mathrm{Ni}, \mathrm{Cu}, \mathrm{Zn}, \mathrm{Cd}$, $\mathrm{Rb}, \mathrm{Pb}$ and U, using a VG Plasma Quad Inductively Coupled Plasma-Mass Spectrometer (ICP-MS). Internal standards of In and Pt (at $50 \mu \mathrm{g} \mathrm{L}^{-1}$ ) are used to compensate for instrument drift and matrix effects caused by the relatively high total dissolved solids (TDS) likely in some of the samples. Calibration is carried out for each element using aqueous standards in the range 1-100 $\mu \mathrm{g} \mathrm{L}^{-1}$. Standard reference materials, SLRS2 (National Research Council, Canada) and 1643c (National Bureau of Standards, USA) are used to check the accuracy of the calibrations. Instrument configuration is detailed in Gooddy et al. (1995).

The filtered unacidified water fraction is analysed for Nitrate-nitrogen $\left(\mathrm{NO}_{3}-\mathrm{N}\right)$, ammonium-nitrogen $\left(\mathrm{NH}_{4}-\mathrm{N}\right)$, molybdate-reactive phosphorus (MRP) and Cl using standard Auto Analyser II colorimetric methods (Kinniburgh and Miles, 1983). Organic phosphate is assumed to be the difference between total phosphate and molybdate-reacting phosphate (MRP). To overcome interference problems with the yellow/brown colour of some of the porewaters, samples are run with and without the colour reagent for $\mathrm{Cl}$ analysis and the difference between the two taken as the actual concentration. $\mathrm{NO}_{3}-\mathrm{N}$ is determined by the cadmium column reduction method since the high organic carbon content of the samples caused suppression of the baseline when the hydrazine/copper reduction method was used. $\mathrm{pH}$ is measured with a glass micro electrode and bicarbonate $\left(\mathrm{HCO}_{3}\right)$ determined with an automated Radiometer titrator. Specific electrical conductance (SEC) is measured using a Radiometer conductivity probe and corrected to $25^{\circ} \mathrm{C}$. Dissolved organic carbon (DOC) is measured on the unacidified, unfiltered sample with a Skalar CA 10 TOC analyser.

\subsection{Sulphur and Oxygen Isotopes}

Sulphate from filtered acidified porewaters was precipitated as $\mathrm{BaSO}_{4}$ for gravimetric and isotopic analysis on $\mathrm{SO}_{2}$ prepared by the method of Halas et al. (1982). As concentrations of sulphate were low, several samples from a composite depth range were required to provide sufficient water for the isotopic analysis. Consequently the resolution of this data is poor relative to the other porewater data.

Samples of raw cattle slurry were collected from the storage lagoons at each farm. Three separate aliquots of each sample were treated to extract total sulphur, inorganic sulphate and inorganic sulphides. Organically bound sulphur was calculated by difference.

Sulphate extraction from slurry was done with a dilute nitric acid leach under a nitrogen atmosphere (Louie et al., 1995; Poulton et al., 1996) and precipitated as $\mathrm{BaSO}_{4}$ for gravimetric and isotope analysis. Reduced inorganic sulphur was determined by a modified chromous chloride reduction method (Newton et al 1995). This method reacts chromous chloride with inorganic sulphides in the sample to form hydrogen sulphide which is then trapped as a copper sulphide precipitate (CuS) for isotopic analysis. The residual copper chloride was then back titrated with EDTA to determine the amount of inorganic sulphur present in the samples. Total sulphur was obtained by chemical oxidation 
of all sulphur species with a hot mixture of nitric acid, brominated water and potassium chlorate and subsequent precipitation as $\mathrm{BaSO}_{4}$ for gravimetric and isotope analysis.

Sulphate-oxygen isotopic compositions were determined by reduction with graphite in an induction furnace at approximately $1000^{\circ} \mathrm{C}$ to produce $\mathrm{CO}_{2}$ and $\mathrm{CO}$. Carbon monoxide was then disproportionated to $\mathrm{CO}_{2}$ by sparking of platinum electrodes in a discharge bulb. A residual of $\mathrm{BaSO}_{4}$ within the furnace crucible was reacted with silver nitrate to produce silver sulphide precipitates. These were combusted with $\mathrm{CuO}_{2}$ to yield $\mathrm{SO}_{2}$ for isotopic analysis.

Sample gases were cryogenically purified and analysed on a VG SIRA 10 Mass Spectrometer. Results are reported in standard delta $(\delta)$ notation as parts per thousand deviations relative to the international standards Canyon Diablo Troilite (V-CDT) for sulphur and Standard Mean Ocean Water (V-SMOW) for oxygen. Accuracy of the isotopic analysis determined from analysis of standards is $\pm 0.4 \%$ o for $\delta^{18} \mathrm{O}$ and $\pm 0.2 \%$ for $\delta^{34} \mathrm{~S}$.

\subsection{Gas Samplers}

The gas samplers were made from short lengths of plastic waste pipe perforated with $10 \mathrm{~mm}$ diameter holes at 30-40 mm centres and packed with glass wool to prevent ingress of sand fill around the pipes. Sampler length and diameter were $300 \mathrm{~mm}$ and $43 \mathrm{~mm}$, respectively, for the deeper samplers and $200 \mathrm{~mm}$ and $35 \mathrm{~mm}$, respectively, for the shallow samplers. Samplers were installed at 3.5m, $5.5 \mathrm{~m}$, $7.5 \mathrm{~m}, 10.5 \mathrm{~m}, 14.3 \mathrm{~m}$ and $17.7 \mathrm{~m}$ below ground level (Figure 2b). Each section was isolated from its neighbour by a thick bentonite seal. The samplers were connected to the surface by $6 \mathrm{~mm}$ colour-coded nylon tubing. Each tube has a toggle valve at the top to prevent contamination by the atmospheric gases. Samples were taken about 12 months after installation to ensure equilibration with the unsaturated zone environment based on the experience of Kinniburgh et al. (1999).

Free gases were collected from the installed samplers by connecting an evacuated $300 \mathrm{ml}$ glass bulb to the extraction tube of each sampler. Each bulb had a built-in ' $\mathrm{T}$ ' allowing a hand pump to be attached at the same time as the bulb was connected to the extraction tube. At each sampling, the toggle valve at the end of the extraction tube was opened and the system pumped enough to extract more than three times the volume of the tubing to purge the system. At this stage, the tap on the glass bulb was opened and the bulb allowed to fill with gases from the sampler.

Gas from these bulbs was admitted to the gas chromatograph (GC) through a three way valve with a sampling loop. Nitrogen and oxygen were analysed on an MS5A column at room temperature, using argon as a carrier gas and a thermal conductivity detector (TCD). Carbon dioxide and methane were analysed on a Porapak-Q column at room temperature using a helium carrier gas and TCD and flame ionisation detectors. Nitrous oxide was analysed on a Porapak-Q column using a nitrogen carrier gas and an electron capture detector. Certified gas standards were run with the samples to calibrate the results.

Samples for $\mathrm{N}_{2} / \mathrm{Ar}$ measurement were prepared by gas-pipetting an aliquot of gas into a 'finger'-type vessel containing approximately $0.5 \mathrm{~g}$ of copper flakes. Atmospheric air was sampled in the same way to produce 'air spikes' against which to calibrate the results. The sealed fingers were then heated at $450^{\circ} \mathrm{C}$ for 1 hour in order that all $\mathrm{O}_{2}$ could be removed by the copper. After cooling, the fingers were attached to a VG Optima Mass Spectrometer and analysed by simultaneous measurement of the mass $28\left(\mathrm{~N}_{2}\right)$ and $40(\mathrm{Ar})$ peaks using the approach of Martin et al. (1995). This allows analysis on a dynamic (i.e. constant flow) mass spectrometer, which is an improvement on static mass spectrometry because of the absence of 'cracking' effects in the ion source. A higher precision is therefore possible. Ratios of $\mathrm{N}_{2} / \mathrm{Ar}$ were calculated by reference to the results obtained for air samples. Precision is $\pm 0.2 \%$.

Samples for $\delta^{13} \mathrm{C}$ measurement on $\mathrm{CO}_{2}$ were prepared by extracting the $\mathrm{CO}_{2}$ in the gas remaining after GC and $\mathrm{N}_{2} / \mathrm{Ar}$ analysis by pumping the gas through a liquid nitrogen trap. This caused both $\mathrm{CO}_{2}$ and water vapour to remain after the permanent gases had been pumped away. Water was retained in the trap by substituting a 'slush bath' $\left(-60\right.$ to $70^{\circ} \mathrm{C}$ ) for the liquid $\mathrm{N}_{2}$ trap, while the liberated $\mathrm{CO}_{2}$ was 
refrozen into finger-type vessels using liquid $\mathrm{N}_{2}$. The fingers were then attached to a VG Optima mass spectrometer and their ${ }^{13} \mathrm{C} /{ }^{12} \mathrm{C}$ ratios measured. A carbonate standard was used for calibration purposes. Results are expressed with respect to the PeeDee Belemnite (PDB) standard. Precision of the combined extraction and analysis steps is $\pm 0.1 \%$.

Samples for $\delta^{15} \mathrm{~N}-\mathrm{N}_{2}$ analysis were prepared in a similar way to that for $\mathrm{N}_{2} / \mathrm{Ar}$, with the addition of passing the aliquot of gas through a $\mathrm{CO}_{2}$ absorbent ('Carbosorb') between the sample bulb and finger vessel containing the copper flakes (the presence of $\mathrm{CO}_{2}$ interferes with the mass spectrometer measurement of the $\mathrm{N}_{2}$ mass 29 minor peak). Precision is $\pm 0.2 \%$.

\section{RESULTS}

Chemical parameters of groundwater within Chalk aquifers in the UK have been determined by Edmunds et al (1989) and are shown in Table 1. The study in Berkshire is of an unconfined aquifer, whereas the London Basin is confined. The two have been compared to provide a spectrum of values for UK Chalk groundwaters in southern England. Although there is a good deal of variation between the two, clear water quality trends can be seen. A 'baseline' chalk groundwater would have a conductivity around $700 \mu \mathrm{S} / \mathrm{cm}$, a pH of about 7.5 , roughly $300 \mathrm{mg} / \mathrm{L}$ bicarbonate, $80 \mathrm{mg} / \mathrm{L}$ calcium, $50 \mathrm{mg} / \mathrm{L}$ of chloride and sodium and $6 \mathrm{mg} / \mathrm{L}$ potassium.

\subsection{Site 1}

\subsubsection{Porewater Chemistry}

Porewater data from both vertical and inclined boreholes for Site 1 are shown in Table 2a and Table 2b. All depths are expressed in terms of metres below the ground surface. Observation of the core showed visible slurry along fractures within the chalk matrix. Visual observation of the pore waters showed them to be significantly coloured, with the most contaminated samples dark brown in colour and the lesser contaminated samples a pale yellow. Table $2 \mathrm{a}$ and Table $2 \mathrm{~b}$ demonstrate that the porewaters are grossly contaminated throughout the depth of the two profiles with highest concentrations occurring below $10 \mathrm{~m}$. Bicarbonate and chloride are roughly 10 times baseline concentrations (Table 1) and potassium nearly 2 orders of magnitude greater than baseline. Calcium concentrations are nearly a factor of 10 lower than baseline for the deeper porewaters from both boreholes. Dissolved organic carbon (DOC) and ammonia concentrations are both very high, 2 and 3 orders of magnitude above a typical baseline value.

Porewater profiles of nitrate-N, ammonium-N, DOC, $\mathrm{pH}$, calcium and bicarbonate, chloride, copper and nickel at Site 1 display very similar trends (Figure 3a-i) for boreholes drilled beneath the slurry lagoon and those adjacent to the lagoon. Nitrate-N concentrations are initially between $20-70 \mathrm{mg} / \mathrm{l}$ in the top 3-4 m but then quickly decline to be below the detection limit. Calcium follows a similar trend to nitrate- $\mathrm{N}$ with concentrations rapidly declining to 5-10 mg/l below $6 \mathrm{~m}$. Ammonium-N, DOC and bicarbonate all follow a similar trend showing a rapid rise in concentration below 3-4m. The ammonia-N and bicarbonate both show a sudden dip in concentration in the inclined hole around $12 \mathrm{~m}$ whereas $\mathrm{pH}$ (Figure 3d) shows a sudden increase.

Concentrations of heavy metals such as nickel and copper are all very high and follow the same increasing concentration with depth as DOC (Figures 3h\&i) probably due to the formation of strong organo-metallic complexes.

\subsubsection{Sulphate and Sulphur Isotopes}

Porewater profiles for sulphate, $\delta^{34} \mathrm{~S}-\mathrm{SO}_{4}$ and $\delta^{18} \mathrm{O}-\mathrm{SO}_{4}$ are shown in Figure 4. For both boreholes, sulphate concentrations are about $50 \mathrm{mg} / \mathrm{L}$ or less below $3 \mathrm{~m}$ with a narrow rise in sulphate to about $100 \mathrm{mg} / \mathrm{l}$ in the inclined hole around $12 \mathrm{~m}$. Both the inclined and vertical boreholes show a slight increasing trend with depth for sulphate. There are few data for $\delta^{34} \mathrm{~S}$ although the range is $9.3 \%$ o $(-0.7$ 
- 8.6\%o). Shallow porewaters in the vertical and inclined holes have slightly higher $\delta^{34} \mathrm{~S}$ values than the slurry, whereas the opposite is true in samples below $4.0 \mathrm{~m}$. A relatively large enhancement of $\delta^{34} \mathrm{~S}$ occurs at the same depth as the increase in sulphate at $12 \mathrm{~m}$ in the inclined hole. More data exists for $\delta^{18} \mathrm{O}$ which shows a steadily increasing trend in both boreholes with depth. Values range from $2.1 \%$ in the shallowest sample to about $12 \%$ in the deepest samples.

\subsection{Site 2}

\subsubsection{Porewater Chemistry}

Porewater data from both inclined and vertical boreholes for Site 2 are shown in Table 3a and Table 3b. Cores from Site 2 also contain slurry along fracture planes of the chalk matrix although to a lesser extent then Site 1. Porewaters were again coloured but less so than at Site 1 with the most contaminated samples exhibiting a pale yellow colour. Porewater profiles (Figure 5) define different trends in the inclined and vertical boreholes, which suggests that the boreholes intersect different parts of the contaminant plume. Generally, concentrations of chloride, bicarbonate, sulphate, DOC and ammonium- $\mathrm{N}$ are all highest in the inclined borehole in contrast to the vertical borehole where concentrations of nitrate and calcium are higher. Relative to baseline (Table 1) mean chloride concentrations are 5 times higher in the vertical borehole and an order of magnitude higher in the inclined borehole. DOC and bicarbonate both show a trend of increasing concentration with depth in the inclined borehole, reaching a peak at around $16 \mathrm{~m}$ before concentrations start to decline. Concentrations of DOC and bicarbonate in the vertical borehole are considerably lower than the inclined hole and remain fairly constant through out the profile. Nitrate- $\mathrm{N}$ in the inclined borehole shows a rapid increase in concentration to a peak around $8 \mathrm{~m}$ before showing a rapid decline in concentration. In the vertical borehole, nitrate-N has a higher initial concentration, rising to a peak at about $4 \mathrm{~m}$ before also rapidly decreasing and following a fairly constant concentration throughout the rest of the profile. Ammonium- $\mathrm{N}$ is detected in the inclined borehole at depths beyond $12 \mathrm{~m}$ but is only found in the vertical borehole in the top $50 \mathrm{~cm}$.

Trace metal concentrations of copper and nickel also high with highest concentrations found in porewaters from the inclined borehole (Figures $5 \mathrm{~h} \& \mathrm{i}$ ).

\subsubsection{Sulphate and Sulphur Isotopes}

Porewater profiles for sulphate, $\delta^{34} \mathrm{~S}-\mathrm{SO}_{4}$ and $\delta^{18} \mathrm{O}-\mathrm{SO}_{4}$ are shown in Figure 6. Sulphate shows a rising concentration trend in both holes. In the inclined borehole sulphate concentrations peak around $10 \mathrm{~m}$ and then show a slight decrease in concentration down to $16 \mathrm{~m}$. Concentrations in the inclined borehole then continue to increase to the bottom of the borehole. Values for $\delta^{34} \mathrm{~S}$ range by $15.5 \%$ o ($2.5-13 \%$ ) although values in the inclined borehole fall very close to the slurry composition (3.9\%o) between $7-16 \mathrm{~m}$ and show a slight increasing trend. The vertical borehole generally exhibits lower $\delta^{34} \mathrm{~S}$ values than the inclined borehole. Values for $\delta^{18} \mathrm{O}$ range by $7.5 \%$ o $(1.9-9.3 \%$ ), with a decreasing trend down to $8 \mathrm{~m}$ and then an increasing trend to the borehole base. Inclined and vertical boreholes generally follow the same trend.

\subsubsection{Gas Analysis}

Baseline gas sampling data has been prepared by Darling et al. (1997) and this is summarised in Table 4. Site 2 exhibits a radically different gas chemistry relative to baseline and also took considerably longer to equilibrate than samples taken below agricultural grassland (Kinniburgh et al., 1999). Profiles for gas samples taken after 428 and 569 days are shown in Figure 7. Borehole construction and inevitable introduction of atmospheric air had a significant impact on both oxygen and methane concentrations. Carbon dioxide $\left(\mathrm{CO}_{2}\right)$ concentrations have remained remarkably similar from one sampling to the next, showing a marked increase with depth from $6 \mathrm{~m}$ and below. Concentrations of methane at $17 \mathrm{~m}$ depth increased by five orders of magnitude from the first sampling to the second ( $>10 \%$ methane), with the concentration of methane found being of the same 
order of magnitude as that found in landfill sites. By the second round of sampling, this methane concentration has reduced considerably to below $1 \%$. The $\delta^{13} \mathrm{C}-\mathrm{CO}_{2}$ ratio did not change during the large change in methane concentrations.

A high degree of microbial activity is reflected in a high nitrogen to argon ratio, which, for samplers deeper than $7 \mathrm{~m} \mathrm{bgl}$ sampled after 428 and 569 days averages $90.54 \pm 4.86$. The maximum in $\mathrm{N}_{2} \mathrm{O}$ concentration occurs at around $10 \mathrm{~m}$, although the peak in the nitrogen to argon ratio occurs around $15 \mathrm{~m}$ bgl, coincident with a minimum of $\mathrm{N}_{2} \mathrm{O}$ and a maximum of $\delta^{15} \mathrm{~N}$.

\section{DISCUSSION}

The porewater chemistry displays clear indications of slurry infiltrating the Chalk at both sites. Unpolluted groundwaters in the Chalk are predominantly a calcium carbonate type and slurry infiltration is readily identified by high concentrations of sulphate, nitrogen species (nitrate or ammonium), chloride, organic carbon and much greater concentrations of bicarbonate. These constituents correspond with those associated with cattle slurry by previous studies (Gooddy et al., 1998; Hooda et al., 2000).

The similarity between inclined and vertical borehole concentrations at Site 1 indicates a large component of the slurry is migrating through the side of the pit walls and causing considerable contamination in porewaters adjacent to the pit. At Site 2, the pit is still impacting the adjacent porewaters but to a lesser degree as reflected by a $50 \%$ difference in chloride concentration between the inclined borehole and the vertical borehole.

A major component of the slurry is organic matter as indicated by high dissolved organic carbon values. Within the slurry/chalk matrix system, the primary TEA's available for microbial degradation comprise dissolved oxygen, nitrate and sulphate. By examining the profiles at Sites 1 and 2, distinct geochemical processes can be seen associated with degradation of the slurry and the consumption of available TEA's. The region of aerobic respiration is apparent by the presence of nitrate and sulphate at high concentrations, which are removed by anaerobic respiration in the sub-oxic section of the profiles. In both cases, the aerobic zone is considerably thinner than normally found in a pristine chalk aquifer as this would usually extend throughout the depth of the unsaturated zone to the water table.

\subsection{Aerobic and Anaerobic Zones - Site 1}

At Site 1, a rapid reduction in nitrate- $\mathrm{N}$ concentrations and rise in ammonium-N concentration begins just below the ground surface. This is likely to be due to the ingress of ammonium- $\mathrm{N}$ from the mineralisation of organic nitrogen in the slurry rather than nitrate reduction. Depletion of sulphate concentrations occurs at a similar depth to the increase in ammonium- $\mathrm{N}$. The $\delta^{34} \mathrm{~S}-\mathrm{SO}_{4}$ shows a clear enrichment relative to the slurry composition at $12 \mathrm{~m}$ although this occurs in the same zone where an increase in sulphate is observed. It is unclear why sulphate and $\mathrm{pH}$ increases at $12 \mathrm{~m}$ whilst ammonium- $\mathrm{N}$ and bicarbonate decrease. In a previous study (Gooddy et al., 1998) similar behaviour was encountered and explained in terms of the dual porosity of the aquifer, with contaminated porewater intercepting a relatively oxygen rich fracture in the chalk. However, with the decline in ammonium- $\mathrm{N}$ and bicarbonate concentrations $\mathrm{pH}$ also decreased, whereas nitrate- $\mathrm{N}$ and calcium concentrations increased. In the current study no such rise in calcium or nitrate concentrations is found. It is suggested therefore that at $12 \mathrm{~m}$ in the inclined borehole, conditions are less reducing than in the $8 \mathrm{~m}$ above and the $4 \mathrm{~m}$ below, but the reason is unresolved. The steady shift in the enrichment of both $\delta^{34} \mathrm{~S}-\mathrm{SO}_{4}$ and $\delta^{18} \mathrm{O}-\mathrm{SO}_{4}$ with depth strongly suggests BSR is taking place, although the paucity of $\delta^{34} \mathrm{~S}_{-} \mathrm{SO}_{4}$ data makes it hard to confirm from this measurement alone. Enrichment in the $\delta^{18} \mathrm{O}-\mathrm{SO}_{4}$ occurs despite a slight increase the sulphate concentration. This may infer that sulphate concentrations were initially higher and the approximately $50 \mathrm{mg} / \mathrm{l}$ concentration that occurs below $3 \mathrm{~m}$ represents a threshold level for the viability of BSR in this system. Alternatively it is possible that the isotopic 
composition of the stored cattle slurry has changed markedly over the 20 year period that the pit has been in operation, indeed the difference between the cattle slurry at chalk Site 1 and chalk Site 2 is some $2 \%$.

\subsection{Aerobic and Anaerobic Zones - Site 2}

Gas samplers located in the inclined hole show unsaturated zone oxygen gas concentrations between $13-17 \%$ in the top $7.5 \mathrm{~m}$ of the borehole (Figure 7a). Sufficient oxygen is able to diffuse into the top of the profile to facilitate the oxidation of ammonium derived from the mineralisation of the slurry. The vertical hole appears to remain relatively aerobic throughout its depth but is characterised by high concentrations of nitrate. These possibly arrive through dispersion of ammonia from the contaminant plume and its consequent oxidation, or from dispersion and dilution of nitrate from beneath the pit.

In the inclined borehole, nitrate- $\mathrm{N}$ concentrations decrease four fold over a distance of roughly $6 \mathrm{~m}$ between $8-14 \mathrm{~m}$. The higher concentrations of DOC (Figure 5c) and absence of oxygen (Figure 7a) demonstrate that this region is anaerobic and data from the gas samplers (Figures 7b,c and g) indicates denitrification occurs over this depth range. The concurrence of a maximum in the $\mathrm{N}_{2} / \mathrm{Ar}$ ratio and the $\delta^{15} \mathrm{~N}-\mathrm{N}_{2}$ and a minimum in the $\mathrm{N}_{2} \mathrm{O}$ concentration at 14 m suggest most denitrification is occurring at this point in the profile.

A slight decrease in sulphate concentration in the inclined borehole occurs between 8 and 16 and this is accompanied by a slight shift in $\delta^{34} \mathrm{~S}_{-} \mathrm{SO}_{4}$ and $\delta^{18} \mathrm{O}-\mathrm{SO}_{4}$ over the same depth range. This suggests that BSR is taking place and occurs at the same time as denitrification.

A high in $\delta^{34} \mathrm{~S}_{-} \mathrm{SO}_{4}$ occurs at the base of the inclined borehole where concentrations of ammonium-N start to rise and a very high concentration of methane was observed in the gas sampler (Figure 7e). It is suggested that during the evolution of the profile, conditions at depth may have been more reducing. This is consistent with the concept of an initial contaminant pulse migrating through the profile in the early years of the slurry lagoon operation, prior to the lagoon base sealing.

\subsection{Degradation of Organic Carbon}

The combination of aerobic and anaerobic respiration must be producing carbon dioxide and bicarbonate respectively as products. It would be anticipated that these products would in turn coincide with the aerobic and anaerobic regions. In practice this can be seen, with a large increase in bicarbonate immediately below the aerobic zone associated with anaerobic respiration. The predominance of bicarbonate corroborates the evidence that anaerobic respiration is prevailing over both profiles for Site 1 and the inclined profile for Site 2. The degradation of organic carbon is well demonstrated at Site 2 by comparing the inclined borehole profile for DOC with that of a conservative element such as chloride. Chloride remains fairly constant in concentration from $4 \mathrm{~m}$ bgl to the profile base but a dramatic rise is seen in DOC concentrations between 12 and $14 \mathrm{~m}$ bgl which indicates considerable degradation between 4 and $12 \mathrm{mbgl}$. Anaerobic respiration is a much less efficient process than its aerobic counterpart and will not result in degradation of the plume to the same extent as if an aerobic zone were present. DOC increases inversely with depth in the anaerobic profile as more organic matter survives microbial attack. The greater efficiency of aerobic oxidation over denitrification is demonstrated by the lower DOC concentrations in the vertical borehole at Site 2 compared with the inclined borehole. Similarly, the greater efficiency of denitrification over BSR is demonstrated by the considerably lower DOC concentrations found in the inclined borehole at Site 2 compared with Site 1.

With the small pore-neck size of the chalk aquifer matrix, it must be inferred that the microbes responsible for degradation of organic carbon reside in the fractures and the microbial population is largely derived from the slurry material. 


\subsection{Carbonate Dissolution and Precipitation}

Based on the dichotomy of aerobic and anaerobic process in the profiles an associated reverse in the direction of carbonate equilibria is anticipated with depth in the profile. According to carbonate equilibrium and Le Chattelier's principle, excess carbon dioxide generation and in turn proton liberation (by disassociation of $\mathrm{H}_{2} \mathrm{CO}_{3}$ ) in the aerobic profile is likely to result in the dissolution of calcite. Conversely, anaerobic reduction of organic matter will result in the formation of bicarbonate promoting saturation and precipitation of calcite. There is evidence to suggest calcite dissolution in the aerobic portion of the profiles as shown by the presence of calcium, formed by dissociation of chalk. However, over the majority of the profiles bicarbonate is generated leading to calcite precipitation. As would be expected based upon carbonate equilibria, bicarbonate and calcium are inversely related. The cross over between aerobic and anaerobic boundaries is evidenced by the rapid depletion of calcium and increased concentrations of bicarbonate.

Data for calcite and dolomite saturation are shown in Figure 8. Saturation indices have been calculated by using PHREEQC (Parkhurst and Appelo, 1999). The temperature has been assumed as $10^{\circ} \mathrm{C}$ as no data is available for the temperature of the extracted porewaters and this is assumed a reasonable average for UK groundwaters (Edmunds et al., 1989). The porewaters are supersaturated with respect to both calcite and dolomite. Supersaturation of calcite has been observed previously for waters where high concentrations of organic matter are present (Amrhein and Suarez, 1987; Inskeep and Bloom, 1986).

Gas sampler data from Site 2 (Figures $7 \mathrm{~d}$ and $\mathrm{f}$ ) shows rising concentrations of $\mathrm{CO}_{2}$ and $\delta^{13} \mathrm{C}-\mathrm{CO}_{2}$ becoming less negative. As the $\delta^{13} \mathrm{C}-\mathrm{CO}_{2}$ of organic matter tends to be around $-24 \%$ and the mean $\delta^{13} \mathrm{C}-\mathrm{CO}_{2}$ of chalk in southern England is $+1.9 \%$ (Downing et al., 1979), a positive shift suggests some carbonate dissolution. This could have happened early in the life of the slurry lagoon when the sub-surface environment was aerobic throughout and migrating ammonium could be oxidised to nitrate.

\subsection{Uranium in Porewaters}

A cross plot of uranium and bicarbonate is shown in Figure 9. For all but the vertical borehole at Site 2, where oxygen appears to be freely available, a reasonable positive correlation is observed. Uranium forms strong complexes with bicarbonate which helps to keep it in solution (Elless and Lee, 1998). One possible source of the uranium is from the Chalk matrix itself. However, it is likely that the uranium originates from another source rather than dissolution reactions since the correlation is best for boreholes where conditions are reducing and calcite is being precipitated. It has previously been postulated by Gooddy et al. (1998) that NPK fertilisers could be the origin of the uranium since phosphate rocks used in the manufacture of these products are rich in uranium, typically containing $10-100 \mathrm{mg} / \mathrm{kg}$ (Zielinski et al., 2000). Although originating from phosphate, no clear relation is observed between uranium and total phosphate. The uranium could be released by mineralisation from any complex formed with phosphate in the slurry store or in the upper part of the contaminant plume prior to transport through the profile as a soluble carbonate.

\section{CONCLUSIONS}

A combination of geochemical techniques have been used to determine plume development and attenuation beneath two unlined slurry lagoons on the chalk. These techniques have eluded to a deep zone of sulphate reduction beneath Site 1 and a deep zone of denitrification with some sulphate reduction beneath Site 2 . The sites differ significantly in design with the fully submerged design of Site 1 producing a larger contaminant footprint than Site 2. This is concluded from the similar concentrations found in porewater chemistry for the inclined and vertical boreholes at Site 1. 
The large contaminant loading beneath Site 1 suggests that it is continuing to leach contaminants into the aquifer as an impermeable seal has not been formed. Site 2 is still exhibiting a contaminant loading on the aquifer but this is substantially less than Site 1. It is possible that the raised design has allowed greater ingress of oxygen and more degradation of the slurry has been able to occur in the pit itself. The presence of methane, elevated ammonia concentrations and an enhancement of $\delta^{34} \mathrm{~S}_{-} \mathrm{SO}_{4}$ at depth however, suggest that a large pulse of contamination has already passed through the unsaturated zone and what is observed now is the unsaturated zone in a state of recovery. The lagoon has formed a sealed base relatively early in its lifetime and the contaminant plume originates from the early operation of the store.

Trace elements present in the slurry have been transported through the unsaturated zone as organometallic complexes. In addition, it has been suggested that uranium originating from NPK fertilisers used in cattle feedstocks, has been transported through the unsaturated zone as carbonate complexes due to the formation of bicarbonate produced in the reduction process.

In the absence of a significant aerobic zone it seems unlikely that the cattle slurry will be fully degraded in the chalk. The other available redox drivers have all originated from the slurry itself. There is a significant risk of effluent migration to the water table from both sites.

\section{ACKNOWLEDGEMENTS}

This work has been undertaken with funding from the UK Ministry of Agriculture, Fisheries and Food (MAFF). The author is grateful to Mike Bird and Janice Trafford of BGS Wallingford for carrying out the field study and chemical analyses respectively. Daren Gooddy publishes with the permission of the Director of the British Geological Survey (NERC).

\section{REFERENCES}

Amrhein, C., Suarez, D.L., 1987. Calcite supersaturation in soils as a result of organic-matter mineralization. Soil Science Society of America Journal 51, 4, 932-937.

Barrington, S.F., Jutras, P. J., Broughton, R. S., 1987. The sealing of soils by manure. I. Preliminary investigations. Canadian Agricultural Engineering 29, 2, 99-103.

Darling, W.G., Kinniburgh, D.G., Gooddy, D.C., 1997. Gas compositions and processes in the unsaturated zone of the Chalk and Triassic Sandstone aquifers, England. In 'Isotope techniques in the Study of Environmental Change'. Proceedings IAEA Symposium, 14-18 April 1997, 265-274.

Downing, R.A., Pearson, F.J., Smith, D.B., 1979. The flow mechanism in the Chalk based on radioisotope analyses of groundwater in the London Basin. Journal of Hydrology 40, 67-83.

Edmunds, W.M., Bath, A.H., 1976. Centrifuge extraction and chemical analysis of interstitial waters. Environmental Science and Technology 10, 467-472.

Edmunds, W.M., Cook J.M., Kinniburgh D.G., Miles, D.L., Trafford, J.M. 1989., Trace element occurrence in British Groundwaters. British Geological Survey Research Report SD/89/3.

Elless, M.P., Lee, S.Y., 1998. Uranium solubility of carbonate-rich uranium-contaminated soils. Water, Air and Soil Pollution 107, 147-162.

Fritz, P., Barshamal, G.M., Drimnie, R.S., Ibsen. J., Qureshi, R. M., (1989). Oxygen isotope exchange between sulphate and water during bacterial reduction of sulphate. Chemical Geology 79, 99-105.

Gooddy, D.C., Shand, P., Kinniburgh, D.G., Van Riemsdijk, W.H., 1995. Field-based partition coefficients for trace elements in soil solutions. European Journal of Soil Science 46, 265-285.

Gooddy, D.C., Withers, P.J.A., McDonald, H. G., Chilton, P.J., 1998. Behaviour and impact of cow slurry beneath a storage lagoon: II. Chemical composition of chalk porewater after 18 years. Water, Air and Soil Pollution 107, 51-72. 
Gooddy, D.C, Hughes, A.G., Williams, A.T., Armstrong, A.C., Nicholson R.J., Williams, J.R., 2001. Field and modelling studies to assess the risk to UK groundwater from earth-based stores for livestock manure. Soil Use and Management 17, 128-137.

Gooddy D C. Movement of leachate from beneath turkey litter sited over Chalk in southern England. 2002. Journal of Environmental Science and Health, Part B - Pesticides, food contaminants, and agricultural wastes B37, 1.

Halas, S., Shakur, A., Krouse, H. R., 1982. A modified method of $\mathrm{SO}_{2}$ extraction from sulphates for isotopic analysis using NaPO3. Isotopenpraxis 18, 11-13.

Hooda, P.S., Edwards, A.C., Anderson, H.A., Miller, A. 2000. A review of water quality concerns in livestock farming areas. Science of the Total Environment 250, 143-167.

Inskeep, W.P., Bloom, P.R., 1986. Kinetics of calcite precipitation in the presence of water-soluble organic-ligands. Soil Science Society of America Journal 50, 5, 1167-1172.

Kanazawa, K., Miyaji, N., Kusaba, T., Ban, K., Hayakawa, Y., Hatano, R., 1999. Groundwater pollution by cattle slurry stored in unlined lagoon. Japan Agriculture Research Quarterly 33, $1,7-13$.

Kinniburgh, D.G, Gale, I.N., Gooddy, D.C., Darling, W.G., Marks, R.,J., Gibbs, B.R., Coleby, L.M., Bird, M.J., West, J.M., 1999. Denitrification in the unsaturated zones of the British Chalk and Sherwood Sandstone aquifers. British Geological Survey Technical Report WD/99/2.

Kinniburgh, D.G., Miles, D., L., 1983. Extraction and chemical analysis of interstitial water from soils and rocks. Environmental Science and Technology 17, 362-368.

Lawrence, A.R., Gooddy D.C., Kanatharana, P., Meesilp, W., Ramnarong, V. 2000. Groundwater evolution beneath Hat Yai, a rapidly developing city in Thailand. Hydrogeology Journal 8, 564-575.

Louie, P.K.K., Bottrell, S.H., Timpe, R.C., Hawthorne, S.B., Miller, D.J., 1995. An improved method for extracting sulphate from bituminous coals using formic acid. Fuel 74, 1480-1484.

Mariotti, A., Landreau, A. Simon, B., 1988. ${ }^{15} \mathrm{~N}$ isotope biogeochemistry and natural denitrification process in groundwater: application to the chalk aquifer in northern France. Geochemica et Cosmochemica Acta 52, 1869-1878.

Martin, G.E., Snow, D.D., Kim, E., Spalding, R.,F., 1995. Simultaneous determination of argon and nitrogen. Ground Water 33, 781-785.

Miller, M.H., Robinson, J.,B., Gillham, R., W., 1985. Self-sealing earthen liquid manure storage ponds:I. A case study. Journal of Environmental Quality, 14, 4, 533-538.

Murphy, A., M., 1998. Unpublished PhD Thesis, Kingston University UK. Sediment and groundwater geochemistry of the Chalk in southern England.

Nakai, N., Jensen, M.L., 1964. The kinetic isotope effect in the bacterial reduction and oxidation of sulphur. Geochemica et Cosmochimica Acta 28, 1893-1912.

Newton, R., Bottrell, S., Dean, S., Hatfield, D., Raiswell, R. 1995. An evaluation of the use of the chromous chloride reduction method for isotopic analyses of pyrite rocks in rocks and sediment. Chemical Geology 125, 317-320.

Nicholson, R., J., Brewer A. ,J., 1997. Estimates of volumes and exposed surface areas of stored animal manures and slurries in England and Wales. Journal of Agricultural Engineering Research 66, 4, 239-250.

Oliver, J.O., Fairbank, W.C., Meyer, J.L., Rible, J.,M., 1974. Subfloor monitoring of Shady Grove liquid manure holding pond. Californian Agriculture 28, 4, 6-7.

Parkhurst, D.L., Appelo, C.A.J., 1999. User's Guide to PHREEQC (Version 2) - A Computer Program for Speciation, Batch-Reaction, One-Dimensional Transport, and Inverse Geochemical Calculations. U.S. Geological Survey Water-Resources Investigations Report 99-4259, 312 p.

Poulton, S. W., Bottrell, S. H., Underwood, C. J. 1998. Porewater sulphur geochemistry and fossil preservation during phosphate diagenesis in a Lower Cretaceous shelf mudstone. Sedimentology. 45. 875-887.

Price, M., Bird, M.J. Foster, S.S.D., 1976. Chalk pore-size measurements and their significance. Water Services 80, 596-600. 
Price, M., 1987. Fluid flow in the Chalk if England. In Fluid flow in sedimentary basins and aquifers, Eds Goff, J.J., Williams, B.P.J., Geological Survey Special Publication No 34, 141-156.

Ritter, W.H., Chirnside, A.E.M., 1983. Influence of animal waste lagoons on ground-water quality. American Society of Agricultural Engineers, paper 83-4573, 34p.

Robinson, F.E., 1973. Changes in seepage rate from an unlined cattle waste digestion pond. Transactions of the American Society of Agricultural Engineers 16, 95-96.

Rowsell, J.G., Miller, M.H., Groenevelt, P.H., 1985. Self sealing of earthen liquid manure storage ponds: II. Rate and mechanism of sealing. Journal of Environmental Quality 14, 4, 539-543.

Sewell, J.I., Mullins, J.A., Vaigneur, H.O., 1975. Dairy lagoon system and groundwater quality. In 'Managing livestock wastes', pp286-288. Proceedings of the Third International Symposium on Livestock Wastes, Urban-Champaign, IL. 21-24 April 1975. American Society of Agricultural Engineers, St. Joseph, MI.

Withers, P.J.A., McDonald, H.G., Smith, K.A., Chumbley, C.G., 1998. Behaviour and impact of cow slurry beneath a storage lagoon: I. Groundwater contamination 1975 - 1982. Water, Air and Soil Pollution 107, 35-49.

Zielinski, R.A., Simmons, K.R., Orem, W.H., 2000. Use of $234 \mathrm{U}$ and $238 \mathrm{U}$ isotopes to identify fertilizer derived uranium in the Florida Everglades. Applied Geochemistry 15, 3, 369-385. 
Table 1. Mean concentrations of groundwater sampled from Chalk of England (Data from Edmunds et al, 1989)

\begin{tabular}{|c|c|c|c|c|c|c|c|c|c|c|}
\hline & $\begin{array}{c}\text { SEC } \\
\mu \mathrm{S} / \mathrm{cm}\end{array}$ & $\mathrm{pH}$ & $\mathrm{Cl}$ & $\mathrm{HCO}_{3}$ & $\mathrm{SO}_{4}$ & $\begin{array}{c}\mathrm{NO}_{3}-\mathrm{N} \\
-\quad \mathrm{mg} / \mathrm{L} \\
\end{array}$ & $\mathrm{Na}$ & $\mathrm{K}$ & $\mathrm{Ca}$ & $\mathrm{Mg}$ \\
\hline \multicolumn{11}{|l|}{ Site } \\
\hline Berkshire $(n=26)$ & 320 & 7.9 & 40 & 304 & 33 & 3.1 & 23 & 5.3 & 86 & 13 \\
\hline London Basin $(n=21)$ & 931 & 7.2 & 65 & 340 & 118 & 1.5 & 100 & 8.1 & 74 & 21 \\
\hline Combined $(n=47)$ & 676 & 7.6 & 51 & 326 & 71 & 1.9 & 57 & 6.1 & 82 & 17 \\
\hline
\end{tabular}


Table 2a. Porewater data from vertical borehole at Site 1

\begin{tabular}{|c|c|c|c|c|c|c|c|c|c|c|c|c|c|c|c|c|c|c|c|c|c|c|c|c|c|c|c|c|c|c|c|c|}
\hline $\begin{array}{l}\text { Depth } \\
\text { m }\end{array}$ & $\begin{array}{r}\text { SEC } \\
\mathrm{mS} / \mathrm{cm}\end{array}$ & $\mathrm{H}$ & $\begin{array}{c}\mathrm{DOC} \\
\mathrm{mg} / \mathrm{l}\end{array}$ & $\begin{array}{c}\mathrm{HCO}_{3} \\
\mathrm{mg} / \mathrm{l}\end{array}$ & $\begin{array}{r}\mathrm{Cl} \\
\mathrm{mg} / \mathrm{l}\end{array}$ & $\begin{array}{l}{ }_{3}-\mathrm{N} \\
\mathrm{mg} / \mathrm{l}\end{array}$ & $\begin{array}{l}\mathrm{H}_{4}-\mathrm{N} \\
\mathrm{mg} / \mathrm{l}\end{array}$ & $\begin{array}{c}\mathrm{SO}_{4} \\
\mathrm{mg} / \mathrm{l}\end{array}$ & $\begin{array}{l}\text { P-tot } \\
\mathrm{mg} / \mathrm{l}\end{array}$ & $\begin{array}{r}\text { P-org } \\
\mathrm{mg} / \mathrm{l}\end{array}$ & $\begin{array}{r}\mathrm{Na} \\
\mathrm{mg} / \mathrm{l}\end{array}$ & $\begin{array}{l}\mathrm{K} \\
\mathrm{g} / \mathrm{l}\end{array}$ & $\begin{array}{r}\mathrm{Ca} \\
\mathrm{mg} / \mathrm{l}\end{array}$ & $\begin{array}{c}\mathrm{Mg} \\
\mathrm{mg} / \mathrm{l}\end{array}$ & $\begin{array}{r}\mathrm{Si} \\
\mathrm{mg} / \mathrm{l}\end{array}$ & $\begin{array}{l}\mathrm{e}-\mathrm{tot} \\
\mu \mathrm{g} / \mathrm{l}\end{array}$ & $\begin{array}{r}\mathrm{Al} \\
\mu \mathrm{g} / \mathrm{l}\end{array}$ & $\begin{array}{r}\text { B } \\
\mu \mathrm{g} / \mathrm{l}\end{array}$ & $\begin{array}{r}\mathrm{Sr} \\
\mu \mathrm{g} / \mathrm{l}\end{array}$ & $\begin{array}{r}\mathrm{Ba} \\
\mu \mathrm{g} / \mathrm{l}\end{array}$ & $\begin{array}{r}\mathrm{Cr} \\
\mu \mathrm{g} / \mathrm{l}\end{array}$ & $\begin{array}{c}\mathrm{Mn} \\
\mu \mathrm{g} / \mathrm{l}\end{array}$ & $\begin{array}{r}\mathrm{Co} \\
\mu \mathrm{g} / \mathrm{l}\end{array}$ & $\begin{array}{r}\mathrm{Ni} \\
\mu \mathrm{g} / \mathrm{l}\end{array}$ & $\begin{array}{r}\mathrm{Cu} \\
\mu \mathrm{g} / \mathrm{l}\end{array}$ & $\begin{array}{r}\mathrm{Zn} \\
\mu \mathrm{g} / \mathrm{l}\end{array}$ & $\begin{array}{r}\mathrm{Cd} \\
\mu \mathrm{g} / \mathrm{l}\end{array}$ & $\begin{array}{r}\mathrm{Pb} \\
\mu \mathrm{g} / \mathrm{l}\end{array}$ & $\begin{array}{r}\mathrm{Rb} \\
\mu \mathrm{g} / \mathrm{l}\end{array}$ & $\begin{array}{r}\mathrm{Y} \\
\mu \mathrm{g} / \mathrm{l}\end{array}$ & $\begin{array}{c}\mathrm{Mo} \\
\mu \mathrm{g} / \mathrm{l}\end{array}$ & $\begin{array}{r}\mathrm{U} \\
\mu \mathrm{g} / \mathrm{l}\end{array}$ \\
\hline 1.8 & & 13 & & & 248 & & & 200 & 3 & 1.8 & 70.2 & 31 & 137 & 26.4 & 6.8 & 10 & .8 & 162 & 364 & 35 & .41 & 6.4 & 8 & 25 & 21 & 70 & 17 & 55 & 92 & 6 & 12 & .39 \\
\hline 3.4 & 76 & 70 & 1.0 & 2 & 75 & & 45 & 34.6 & 4 & 3.7 & 28.4 & 346 & 53.9 & 13.5 & 9.23 & 13 & 12.6 & 192 & 206 & 4 & 41 & 12.0 & 15 & 71 & 10 & 45 & .15 & 0.55 & 98 & 07 & 3 & 8 \\
\hline 4.1 & 39 & 96 & .4 & 10 & 38 & & 4 & 48.9 & 7. & 6. & 43.1 & 5 & 1.6 & 12.5 & .56 & 49 & 31.4 & 147 & 110 & 87 & 0.9 & 9.6 & 20 & 77 & 19 & 87 & .34 & .46 & 103 & 15 & 30 & .08 \\
\hline 4.9 & 14 & 8.07 & 5.9 & 30 & 287 & 1. & 0 & 28.4 & 11.6 & 11.1 & 84.3 & 798 & 58.8 & 38.4 & 14.4 & 83 & 7.7 & 205 & 241 & 185 & 0.37 & 3.8 & 23 & 132 & 47 & 48 & 0.20 & 2.50 & 110 & 0.05 & 11 & 1.40 \\
\hline 5. & & 16 & 6.6 & 90 & 4 & 0 & 10 & 30.5 & 12.3 & 8.3 & 87.7 & 800 & 28.1 & 29.8 & 12.8 & 99 & 18.4 & 156 & 109 & 278 & 0.89 & 5.7 & 22 & 116 & 32 & 67 & 0.40 & 2.87 & 235 & .10 & .7 & 2.13 \\
\hline 6.3 & 99 & 8.14 & 129.8 & 2480 & 333 & 0. & 270 & 28.5 & 16.7 & 14.5 & 95.2 & 878 & 21.1 & 29 & 13.5 & 95 & 23.2 & 188 & 102 & 329 & 0.90 & 2.9 & 29 & 147 & 38 & 84 & $<0.40$ & 1.39 & 284 & 0.07 & 11 & 2.02 \\
\hline 6.8 & .20 & 17 & 3.8 & 2630 & 44 & 0 & 00 & 27.5 & 14.4 & 7.6 & 101 & 949 & 14.9 & 30.1 & 11.4 & 80 & 13.4 & 162 & 58 & 176 & 0.88 & 3.3 & 25 & 142 & 32 & 53 & $<0.40$ & 2.21 & 315 & 0.20 & 10 & 2.40 \\
\hline 7.3 & 5.54 & 8.11 & 166.1 & 2860 & 348 & 0. & 330 & 34.5 & 13.6 & 15.3 & 108 & 905 & 19.8 & 40.4 & 11.5 & 142 & 22.7 & 165 & 90 & 197 & 1.18 & 5.3 & 54 & 252 & 26 & 69 & $<0.40$ & 3.02 & 362 & 0.16 & 2.9 & 2.46 \\
\hline 7.8 & 28 & 25 & 1.4 & 2710 & 44 & 0. & 50 & 32.3 & 6 . & 5.0 & 110 & 859 & 9.93 & 32.8 & 8.27 & 1 & 22.7 & 151 & 39 & 174 & 1.02 & 3.8 & 55 & 193 & 19 & 63 & $<0.40$ & 1.91 & 318 & 0.11 & .4 & 3.35 \\
\hline 8.5 & 33 & 8.27 & 53.0 & 2780 & 344 & 0. & 370 & 34 & 7.3 & 6.1 & 115 & 837 & 13.1 & 29.5 & 6.32 & 202 & 30.8 & 156 & 44 & 185 & 1.18 & 6.3 & 59 & 267 & 33 & 65 & $<0.40$ & 2.43 & 280 & 0.15 & 2.1 & 3.75 \\
\hline 9.3 & 66 & 8.12 & 172.6 & 2980 & 333 & 2. & 380 & 33 & 4.9 & 3.9 & 117 & 872 & 14.8 & 36.8 & 6.05 & 262 & 40.9 & 205 & 86 & 265 & 2.49 & 7.6 & 57 & 272 & 44 & 104 & $<0.40$ & 3.19 & 308 & 0.11 & 3.9 & 3.03 \\
\hline 9. & 9 & 8.21 & 4.4 & 2910 & 99 & 0 & 390 & 37.7 & 1.6 & 0.6 & 117 & 820 & 8.9 & 29.6 & 3.48 & 334 & 19.3 & 164 & 38 & 178 & 1.11 & 3.5 & 66 & 543 & 71 & 57 & $<0.40$ & 1.81 & 252 & 0.19 & 8 & 4.55 \\
\hline 10.5 & 9 & 8.13 & 5.9 & 3030 & 337 & 3. & 400 & 34.2 & 2 & 1. & 118 & 889 & 11.5 & 33.4 & 3.78 & 3 & 24.9 & 149 & 42 & 159 & 1.33 & 4.7 & 57 & 267 & 34 & 86 & $<0.40$ & 1.71 & 249 & 0.15 & 5.0 & 3.56 \\
\hline 11 & 5.81 & 8.22 & 2.3 & 70 & 344 & 0.7 & 390 & 38.2 & 4.6 & 3.5 & 123 & 903 & 6.59 & 32.1 & 4.02 & 6 & 38.7 & 184 & 46 & 204 & 1.89 & 2.2 & 10 & 508 & 66 & 85 & $<0.40$ & 3.41 & 245 & 0.15 & 1.1 & 3.74 \\
\hline 11.7 & 72 & 8.26 & 21.6 & 3000 & 351 & 0.6 & 390 & 42.4 & 2.1 & 1.0 & 124 & 912 & 5.42 & 29.1 & 3.37 & 652 & 40.7 & 166 & 33 & 113 & 1.98 & 2.5 & 107 & 535 & 73 & 62 & $<0.40$ & 2.53 & 228 & 0.14 & 5.4 & 4.29 \\
\hline 12.8 & 5.13 & 8.37 & 0.0 & 2620 & 344 & 0.6 & 350 & 46.3 & 1. & 0.7 & 112 & 71 & 4.71 & 15.3 & 1.03 & 323 & 14.5 & 163 & 15 & 137 & 1.14 & 2.1 & 79 & 555 & 105 & 50 & 0.76 & 3.45 & 171 & 0.16 & 4.9 & 6.98 \\
\hline 14.3 & 5.24 & 8.37 & 164.8 & 1640 & 403 & 3.5 & 250 & 69.1 & 1.6 & 0.3 & 90.1 & 817 & 6.25 & 6.0 & 2.9 & 83 & 21.3 & 148 & 29 & 161 & 0.97 & 2.1 & 26 & 156 & 220 & 35 & 1.00 & 1.79 & 202 & 0.07 & 330 & 2.41 \\
\hline
\end{tabular}


Table 2b. Porewater data from inclined borehole at Site 1

\begin{tabular}{|c|c|c|c|c|c|c|c|c|c|c|c|c|c|c|c|c|c|c|c|c|c|c|c|c|c|c|c|c|c|c|c|c|}
\hline $\begin{array}{l}\text { epth } \\
\text { m }\end{array}$ & $\begin{array}{l}\text { SEC } \\
\text { S/cm }\end{array}$ & & $\begin{array}{c}\mathrm{DOC} \\
\mathrm{mg} / \mathrm{l}\end{array}$ & $\begin{array}{r}\mathrm{HCO}_{3} \\
\mathrm{mg} / \mathrm{l}\end{array}$ & $\begin{array}{r}\mathrm{Cl} \\
\mathrm{mg} / \mathrm{l}\end{array}$ & $\begin{array}{l}\mathrm{O}_{3}-\mathrm{N} \\
\mathrm{mg} / \mathrm{l}\end{array}$ & $\begin{array}{r}\mathrm{H}_{4}-\mathrm{N} \\
\mathrm{mg} / \mathrm{l}\end{array}$ & $\begin{array}{c}\mathrm{SO}_{4} \\
\mathrm{mg} / \mathrm{l}\end{array}$ & $\begin{array}{l}\mathrm{P} \text {-tot } \\
\mathrm{mg} / \mathrm{l}\end{array}$ & $\begin{array}{r}\text { P-org } \\
\mathrm{mg} / \mathrm{l}\end{array}$ & $\begin{array}{r}\mathrm{Na} \\
\mathrm{mg} / \mathrm{l}\end{array}$ & $\begin{array}{r}\mathrm{K} \\
\mathrm{mg} / \mathrm{l}\end{array}$ & $\begin{array}{r}\mathrm{Ca} \\
\mathrm{mg} / \mathrm{l}\end{array}$ & $\begin{array}{c}\mathrm{Mg} \\
\mathrm{mg} / \mathrm{l}\end{array}$ & $\begin{array}{r}\mathrm{Si} \\
\mathrm{mg} / \mathrm{l}\end{array}$ & $\begin{array}{l}\text { e-tot } \\
\mu \mathrm{g} / \mathrm{l}\end{array}$ & $\begin{array}{r}\mathrm{Al} \\
\mu \mathrm{g} / \mathrm{l}\end{array}$ & $\begin{array}{r}\mathrm{B} \\
\mu \mathrm{g} / \mathrm{l}\end{array}$ & $\begin{array}{r}\mathrm{Sr} \\
\mu \mathrm{g} / \mathrm{l}\end{array}$ & $\begin{array}{r}\mathrm{Ba} \\
\mu \mathrm{g} / \mathrm{l}\end{array}$ & $\begin{array}{r}\mathrm{Cr} \\
\mu \mathrm{g} / \mathrm{l}\end{array}$ & $\begin{array}{c}\mathrm{Mn} \\
\mu \mathrm{g} / \mathrm{l}\end{array}$ & $\begin{array}{c}\mathrm{Co} \\
\mu \mathrm{g} / \mathrm{l}\end{array}$ & $\begin{array}{r}\mathrm{Ni} \\
\mu \mathrm{g} / \mathrm{l}\end{array}$ & $\begin{array}{c}\mathrm{Cu} \\
\mu \mathrm{g} / \mathrm{l}\end{array}$ & $\begin{array}{r}\mathrm{Zn} \\
\mu \mathrm{g} / \mathrm{l}\end{array}$ & $\begin{array}{r}\mathrm{Cd} \\
\mu \mathrm{g} / \mathrm{l}\end{array}$ & $\begin{array}{r}\mathrm{Pb} \\
\mu \mathrm{g} / \mathrm{l}\end{array}$ & $\begin{array}{c}\mathrm{Rb} \\
\mu \mathrm{g} / \mathrm{l}\end{array}$ & $\begin{array}{r}\mathrm{Y} \\
\mu \mathrm{g} / \mathrm{l}\end{array}$ & $\begin{array}{c}\mathrm{Mo} \\
\mu \mathrm{g} / \mathrm{l}\end{array}$ & $\begin{array}{r}\mathrm{U} \\
\mu \mathrm{g} / \mathrm{l}\end{array}$ \\
\hline 0.4 & & 82 & 26.8 & 5 & 212 & & & 8 & 2 & & 42 & 49 & 40 & & & 66 & 8 & 94 & 0 & 54 & 1 & 3.3 & 2 & 1 & 12 & 44 & 10 & .22 & 12 & .07 & 6 & \\
\hline 1.1 & 05 & 81 & 14.7 & 293 & 326 & 37.0 & 0.1 & 144 & 0.2 & 783 & 4 & 6.8 & 310 & & 1.3 & $<6$ & .0 & 120 & 835 & 5 & 32 & 10.5 & 2 & 24 & 6 & 8 & .10 & 44 & 11 & & 2 & 87 \\
\hline 1.8 & 2.00 & 92 & 24.5 & 473 & 22 & 20.9 & 2.5 & 139 & 0.9 & 431 & .7 & 323 & 118 & 7.4 & 3.2 & $<6$ & .5 & 137 & 320 & 161 & 3.23 & 22.6 & 7 & 33 & 12 & 41 & 0.10 & .23 & 61 & .03 & .9 & 0.98 \\
\hline 2.5 & 3.18 & 96 & 85.4 & 1310 & 99 & 19.2 & 152 & 120 & 7.7 & 6.36 & 91 & 423 & 75.4 & 20.1 & 11.7 & 39 & 15.5 & 154 & 191 & 195 & 0.59 & 77.8 & 8 & 26 & 13 & 52 & $<0.10$ & 0.95 & 108 & .09 & 5.9 & 1.58 \\
\hline 3.2 & 2.11 & .11 & 65.6 & 961 & 102 & 1.0 & 71 & 61.1 & 6.7 & 6.17 & 40.3 & 323 & 78.7 & 17.5 & 11.3 & 14 & 17.8 & 163 & 238 & 180 & 0.35 & 22.3 & 8 & 36 & 8 & 29 & $<0.10$ & 0.36 & 95 & 0.05 & 8.0 & 0.84 \\
\hline 3.9 & 2.32 & 18 & 86.6 & 1140 & 90 & 2.2 & 88 & 8.8 & 8.4 & 7.57 & 4.4 & 437 & 45.8 & 7.2 & 11.5 & 20 & 1.5 & 192 & 164 & 168 & 0.46 & 11.3 & 13 & 52 & 8 & 43 & 0.14 & 1.05 & 110 & 0.09 & 3.0 & 1.11 \\
\hline 4.5 & 4.72 & 12 & 169.6 & 2280 & 288 & 1.1 & 255 & 38.2 & 12.9 & 10.6 & 33.7 & 834 & 23.1 & 29.1 & 12.5 & 134 & 21.1 & 173 & 92 & 215 & 1.04 & 4.8 & 18 & 91 & 14 & 56 & $<0.40$ & 1.81 & 256 & 0.07 & 28.1 & 2.56 \\
\hline 4.8 & 5.40 & 17 & 90.5 & 2660 & 334 & 0.8 & 303 & 36.6 & 20.0 & 11.7 & 97.4 & 948 & 18.4 & 32.9 & 13.3 & 176 & 31.8 & 186 & 74 & 209 & 1.30 & 4.6 & 20 & 110 & 16 & 62 & $<0.40$ & 2.15 & 313 & 0.11 & .1 & 2.84 \\
\hline 5.1 & 5.86 & 8.10 & 168.7 & 2910 & 373 & 0.6 & 335 & 34.8 & 16.6 & 13.7 & 105 & 990 & 23.9 & 40.7 & 12.8 & 141 & 23.2 & 191 & 96 & 218 & 1.14 & 5.4 & 33 & 212 & 18 & 51 & $<0.40$ & 1.81 & 358 & 0.10 & 6.8 & 2.48 \\
\hline 5.5 & 5.97 & .09 & 65.9 & 2950 & 381 & & 347 & 0.6 & 13.9 & 3.3 & 107 & 1010 & 20.9 & 1.4 & 13.2 & 19 & 22.8 & 181 & 82 & 172 & 1.21 & 4.2 & 25 & 213 & 8 & 70 & $<0.40$ & 1.39 & 364 & .13 & .1 & 2.47 \\
\hline 5.8 & 5.91 & 8.21 & 168.3 & 2840 & 402 & 0. & 329 & 30.2 & 20.6 & 15.1 & 110 & 947 & 17.9 & 42.2 & 14.7 & 112 & 18.9 & 168 & 73 & 148 & 1.10 & 3.8 & 28 & 181 & 21 & 49 & $<0.40$ & 1.71 & 345 & 0.12 & 2.9 & 2.13 \\
\hline 6.2 & 71 & 04 & 2.5 & 70 & 2 & & 2 & .5 & 0.1 & .3 & 101 & 05 & 23.2 & 4.0 & 13.7 & 101 & 3.4 & 192 & 108 & 170 & 1.22 & 5.4 & 32 & 175 & 18 & 49 & $<0.40$ & .70 & 359 & .08 & 1.1 & .15 \\
\hline 6.7 & 5.40 & .23 & 169.5 & 2510 & 373 & 0.8 & 329 & 35.6 & 21.8 & 10.4 & 105 & 849 & 9.14 & 28.3 & 9.6 & 170 & 29.6 & 175 & 39 & 120 & 1.66 & 2.8 & 81 & 252 & 66 & 42 & $<0.40$ & 1.87 & 319 & 0.09 & 2.0 & 2.75 \\
\hline 7.4 & 5.69 & 24 & 4.3 & 2690 & 2 & & 56 & 7.2 & 6.0 & 10.8 & 107 & 848 & 10.8 & 7.5 & 7.6 & 250 & 4.5 & 176 & 41 & 172 & 1.38 & 5.0 & 87 & 276 & 35 & 50 & $<0.40$ & 1.97 & 309 & 0.06 & 0.8 & 4.01 \\
\hline 8.1 & 4.95 & 8.24 & 154.2 & 2410 & 271 & 0 & 321 & 33.9 & 17.7 & 12.6 & 91.5 & 725 & 9.52 & 26.6 & 9.4 & 158 & 21.8 & 132 & 36 & 153 & 1.12 & 2.6 & 83 & 240 & 35 & 66 & $<0.40$ & 1.47 & 233 & 0.09 & 4.2 & 2.24 \\
\hline 8.7 & 3.98 & 24 & 1.1 & 1870 & 9 & 0.5 & 14 & 5.8 & 2.2 & 1.33 & 2.5 & 600 & 11.0 & 1.0 & 4.8 & 54 & 8.3 & 147 & 34 & 152 & 0.53 & 2.7 & 28 & 139 & 17 & 28 & $<0.40$ & 0.71 & 183 & 0.10 & 3.1 & 3.26 \\
\hline 9.0 & 4.00 & 32 & 31.5 & 1890 & 219 & 0.5 & 248 & 35.5 & 5.9 & 5.09 & 73.6 & 577 & 9.09 & 17.2 & 5.7 & 95 & 13.8 & 151 & 35 & 180 & 1.11 & 4.0 & 49 & 202 & 26 & 45 & $<0.40$ & 0.92 & 170 & 0.10 & 14.7 & 2.71 \\
\hline 9.4 & 18 & 32 & 1.0 & 10 & 40 & & 5 & 9.3 & 8.0 & 6.85 & .9 & 667 & 11.0 & 23.3 & 6.9 & 86 & 3.1 & 148 & 41 & 205 & 0.99 & 3.3 & 52 & 178 & 21 & 41 & $<0.40$ & 1.23 & 237 & 0.09 & 5. & 2.36 \\
\hline 9.7 & 3.99 & 14 & 25.1 & 1880 & 234 & 1 & 250 & 28.5 & 6.7 & 6.36 & 67.5 & 618 & 11.6 & 25.1 & 7.8 & 92 & 18.6 & 119 & 49 & 200 & 0.96 & 3.5 & 70 & 279 & 27 & 59 & $<0.40$ & 1.07 & 197 & 0.14 & 3.2 & 2.07 \\
\hline 10.3 & 41 & 22 & 4.4 & 2190 & 229 & & 0 & 0.3 & 2.5 & 1.86 & 78.3 & 659 & 7.19 & 8.3 & 3.9 & 128 & 7.5 & 153 & 29 & 161 & 0.97 & 3.7 & 64 & 267 & 54 & 45 & $<0.40$ & 1.08 & 204 & 0.14 & 2.4 & 4.26 \\
\hline 10.9 & 94 & 15 & 35.2 & 2360 & 58 & & 9 &. .1 & 2.3 & 1.20 & 94 & 526 & 8.54 & 3.6 & 6.8 & 404 & 38.0 & 207 & 47 & 181 & 1.69 & 3.0 & 40 & 239 & 50 & 54 & $<0.40$ & 1.78 & 213 & 0.13 & 33.2 & 4.16 \\
\hline 11 & 4.92 & 28 & 0.3 & 2340 & 27 & & & 55.6 & 4.5 & 0 & .7 & 742 & 10.3 & 21.4 & 4.4 & 264 & 19.4 & 165 & 35 & 131 & 1.27 & 4.1 & 34 & 448 & 27 & 41 & $<0.40$ & 1.67 & 190 & 0.13 & .5 & 4.91 \\
\hline 11.9 & 3.40 & 80 & 13.6 & 861 & 5 & & 1 & 103 & 2.2 & 0.24 & .9 & 594 & 4.54 & 0.93 & 1.6 & 39 & 8.3 & 294 & 24 & 263 & 1.07 & 1.0 & 9 & 89 & 29 & 19 & 2.76 & 0.55 & 157 & 0.07 & 1000 & 0.40 \\
\hline 12. & 3.24 & 89 & 207.1 & 508 & 519 & & & 104 & 1.8 & 0.16 & 0.5 & 599 & 4.97 & 0.80 & 1.3 & 22 & 13.1 & 253 & 32 & 197 & 1.47 & 2.0 & 12 & 71 & 450 & 32 & 1.66 & 0.59 & 138 & 0.04 & 470 & 1.04 \\
\hline 13.0 & 4.46 & 22 & 187.4 & 140 & 260 & & 71 & 35.1 & 7.4 & 5.29 & 82.9 & 708 & 7.93 & 20.7 & 5.4 & 224 & 26.5 & 146 & 37 & 165 & 2.85 & 5.3 & 71 & 288 & 34 & 49 & $<0.40$ & 1.34 & 154 & 0.10 & 7.4 & 3.20 \\
\hline 13. & 5.44 & 24 & 202.7 & 2690 & 272 & & 338 & 38.8 & 6.0 & 4.31 & 102 & 853 & 6.24 & 24.8 & 5.2 & 437 & 43.5 & 149 & 34 & 110 & 2.15 & 2.5 & 128 & 469 & 51 & 54 & $<0.40$ & 2.41 & 178 & 0.11 & 2.5 & 4.05 \\
\hline 14.1 & 6.34 & 21 & 236.8 & 3190 & 320 & 0. & 411 & 39.7 & 2.8 & 2.02 & 118 & 020 & 5.43 & 28.4 & 4.5 & 773 & 55.8 & 184 & 32 & 151 & 2.32 & 3.0 & 105 & 492 & 72 & 68 & $<0.40$ & 3.41 & 190 & 0.19 & 1.1 & 4.42 \\
\hline 14.6 & 6.14 & 8.24 & 220.7 & 3080 & 329 & 1 & 400 & 37.1 & 1.2 & 0.44 & 114 & 984 & 5.56 & 21.6 & 2.2 & 602 & 25.8 & 189 & 23 & 137 & 1.56 & 2.8 & 63 & 318 & 81 & 66 & 0.66 & 3.50 & 171 & 0.14 & 3.2 & 6.20 \\
\hline 15.1 & 5.73 & 13 & 236.6 & 2830 & 311 & 0 & 352 & 45.7 & 1.6 & 0.74 & 111 & 915 & 6.6 & 22.6 & 3.7 & 496 & 44.2 & 173 & 47 & 156 & 1.98 & 2.3 & 73 & 412 & 55 & 71 & $<0.40$ & 2.32 & 135 & 0.15 & 57.1 & 4.54 \\
\hline 15.6 & 6.45 & 8.20 & 263.3 & 3260 & 345 & & 400 & 48.1 & 2.0 & 1.14 & 122 & 1050 & 5.42 & 22.7 & 3.0 & 670 & 48.9 & 183 & 34 & 125 & 2.20 & 3.2 & 131 & 664 & 126 & 82 & $<0.40$ & 3.71 & 141 & 0.13 & 2.3 & 5.34 \\
\hline 16.2 & 5.99 & 25 & 229.0 & 2890 & 35 & 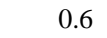 & 389 & 38.7 & 1.2 & 0.54 & 111 & 964 & 4.33 & 14.1 & 2.4 & 430 & 34.0 & 153 & 26 & 170 & 1.63 & 2.1 & 72 & 279 & 82 & 95 & $<0.40$ & 3.80 & 99 & 0.13 & 1.4 & 4.98 \\
\hline 16.7 & 6.64 & 18 & 259.1 & 3330 & 371 & 0.7 & 433 & 43.8 & 1.2 & 0.51 & 124 & 1090 & 5.82 & 20.4 & 2.9 & 594 & 37.0 & 174 & 32 & 174 & 2.02 & 3.3 & 42 & 333 & 57 & 82 & $<0.40$ & 3.13 & 126 & 0.14 & 1.1 & 4.97 \\
\hline
\end{tabular}


Table 3a. Porewater data from vertical borehole at Site 2

\begin{tabular}{|c|c|c|c|c|c|c|c|c|c|c|c|c|c|c|c|c|c|c|c|c|c|c|c|c|c|c|c|c|c|c|c|c|}
\hline $\begin{array}{r}\text { epth } \\
\text { m }\end{array}$ & $\begin{array}{r}\mathrm{SEC} \\
\mathrm{mS} / \mathrm{cm}\end{array}$ & $\mathrm{pH}$ & $\begin{array}{c}\mathrm{DOC} \\
\mathrm{mg} / \mathrm{l}\end{array}$ & $\begin{array}{r}\mathrm{HCO}_{3} \\
\mathrm{mg} / \mathrm{l}\end{array}$ & $\begin{array}{r}\mathrm{Cl} \\
\mathrm{mg} / \mathrm{l}\end{array}$ & $\begin{array}{r}\mathrm{NO}_{3}-\mathrm{N} \\
\mathrm{mg} / \mathrm{l}\end{array}$ & $\begin{array}{r}\mathrm{NH}_{4}-\mathrm{N} \\
\mathrm{mg} / \mathrm{l}\end{array}$ & $\begin{array}{l}\mathrm{SO}_{4} \\
\mathrm{mg} / \mathrm{l}\end{array}$ & $\begin{array}{l}\text { P-tot } \\
\mathrm{mg} / \mathrm{l}\end{array}$ & $\begin{array}{c}\text { P-org } \\
\mathrm{mg} / \mathrm{l}\end{array}$ & $\begin{array}{r}\mathrm{Na} \\
\mathrm{mg} / \mathrm{l}\end{array}$ & $\begin{array}{r}\mathrm{K} \\
\mathrm{mg} / \mathrm{l}\end{array}$ & $\begin{array}{r}\mathrm{Ca} \\
\mathrm{mg} / \mathrm{l}\end{array}$ & $\begin{array}{r}\mathrm{Mg} \\
\mathrm{mg} / \mathrm{l}\end{array}$ & $\begin{array}{r}\mathrm{Si} \\
\mathrm{mg} / \mathrm{l}\end{array}$ & $\begin{array}{r}\text { Fe-tot } \\
\mu \mathrm{g} / \mathrm{l}\end{array}$ & $\begin{array}{r}\mathrm{Al} \\
\mu \mathrm{g} / \mathrm{l}\end{array}$ & $\begin{array}{r}\mathrm{B} \\
\mu \mathrm{g} / \mathrm{l}\end{array}$ & $\begin{array}{r}\mathrm{Sr} \\
\mu \mathrm{g} / \mathrm{l}\end{array}$ & $\begin{array}{r}\mathrm{Ba} \\
\mu \mathrm{g} / \mathrm{l}\end{array}$ & $\begin{array}{r}\mathrm{Cr} \\
\mu \mathrm{g} / \mathrm{l}\end{array}$ & $\begin{array}{c}\mathrm{Mn} \\
\mu \mathrm{g} / \mathrm{l}\end{array}$ & $\begin{array}{r}\mathrm{Co} \\
\mu \mathrm{g} / \mathrm{l}\end{array}$ & $\begin{array}{r}\mathrm{Ni} \\
\mu \mathrm{g} / \mathrm{l}\end{array}$ & $\begin{array}{r}\mathrm{Cu} \\
\mu \mathrm{g} / \mathrm{l}\end{array}$ & $\begin{array}{r}\mathrm{Zn} \\
\mu \mathrm{g} / \mathrm{l}\end{array}$ & $\begin{array}{r}\mathrm{Cd} \\
\mu \mathrm{g} / \mathrm{l}\end{array}$ & $\begin{array}{r}\mathrm{Pb} \\
\mu \mathrm{g} / \mathrm{l}\end{array}$ & $\begin{array}{r}\mathrm{Rb} \\
\mu \mathrm{g} / \mathrm{l}\end{array}$ & $\begin{array}{r}\mathrm{Y} \\
\mu \mathrm{g} / \mathrm{l}\end{array}$ & $\begin{array}{c}\mathrm{Mo} \\
\mu \mathrm{g} / \mathrm{l}\end{array}$ & $\begin{array}{r}\mathrm{U} \\
\mu \mathrm{g} / \mathrm{l}\end{array}$ \\
\hline 0.8 & 4.27 & 7.98 & 27.9 & 279 & 387 & 273 & 2.5 & 147 & 0.6 & 0.20 & 182 & 479 & 239 & 69.3 & 3.56 & $<6$ & 5.2 & 178 & 644 & 353 & 0.94 & 7.9 & 5 & 30 & 19 & 55 & 0.27 & $<0.22$ & 56 & 0.03 & 52.9 & 0.88 \\
\hline 1.5 & 4.70 & 7.86 & 21.8 & 188 & 365 & 358 & $<0.01$ & 117 & 0.3 & 0.14 & 216 & 495 & 253 & 88.4 & 4.73 & 7 & 12.6 & 183 & 839 & 382 & 0.81 & 2.9 & 4 & 23 & 14 & 58 & 0.22 & 0.62 & 76 & 0.03 & 4.2 & 1.01 \\
\hline 2.5 & 4.86 & 7.91 & 26.9 & 186 & 430 & 349 & 0.05 & 111 & 0.4 & 0.14 & 232 & 639 & 199 & 74.2 & 5.2 & 7 & 20.6 & 191 & 711 & 296 & 7.25 & 18.0 & 7 & 33 & 24 & 53 & 0.18 & 0.39 & 99 & 0.07 & 8.3 & 0.94 \\
\hline 3.5 & 5.01 & 7.78 & 16.2 & 199 & 414 & 384 & $<0.01$ & 82.8 & 0.3 & 0.09 & 203 & 636 & 209 & 105 & 3.12 & 7 & 6.8 & 173 & 807 & 319 & 0.48 & 2.6 & 5 & 21 & 14 & 46 & $<0.10$ & 2.33 & 40 & 0.03 & 2.8 & 0.66 \\
\hline 4.5 & 4.46 & 7.95 & 12.7 & 235 & 349 & 317 & $<0.01$ & 97.4 & 0.2 & 0.09 & 157 & 629 & 171 & 88.3 & 3.38 & 130 & 4.5 & 211 & 818 & 328 & 0.26 & 3.1 & 4 & 17 & 16 & 43 & $<0.10$ & $<0.22$ & 34 & 0.03 & 1.9 & 0.65 \\
\hline 5.5 & 4.09 & 7.99 & 13.8 & 225 & 320 & 279 & $<0.01$ & 111 & 0.2 & 0.09 & 132 & 617 & 115 & 80.4 & 2.86 & $<6$ & 3.3 & 189 & 590 & 272 & 0.27 & 2.2 & 4 & 17 & 24 & 46 & 0.17 & 0.40 & 34 & 0.02 & 1.2 & 0.64 \\
\hline 6.5 & 3.81 & 7.93 & 13.9 & 129 & 301 & 261 & 0.17 & 120 & $<0.2$ & 0.07 & 121 & 591 & 102 & 67.0 & 2.3 & $<6$ & 8.6 & 165 & 609 & 233 & 0.48 & 4.7 & 4 & 20 & 21 & 44 & $<0.10$ & $<0.22$ & 37 & 0.03 & 4.0 & 0.48 \\
\hline 7.5 & 3.50 & 7.92 & 11.1 & 131 & 267 & 233 & $<0.01$ & 125 & $<0.2$ & 0.06 & 103 & 562 & 123 & 52.0 & 2.16 & $<6$ & 5.7 & 210 & 723 & 222 & 0.41 & 3.4 & 4 & 16 & 17 & 34 & $<0.10$ & 0.54 & 21 & 0.01 & 0.7 & 0.46 \\
\hline 8.5 & 3.50 & 7.87 & 12.5 & 119 & 275 & 239 & $<0.01$ & 143 & $<0.2$ & 0.05 & 111 & 613 & 118 & 57.4 & 1.98 & $<6$ & 3.0 & 157 & 625 & 215 & 0.31 & 2.9 & 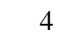 & 18 & 20 & 35 & $<0.10$ & 0.28 & 23 & 0.03 & 0.6 & 0.51 \\
\hline 9.4 & 4.03 & 7.97 & 12.7 & 158 & 329 & 265 & $<0.01$ & 164 & 0.2 & 0.06 & 120 & 673 & 138 & 61.7 & 1.84 & 7 & 3.5 & 137 & 719 & 220 & 0.37 & 3.3 & 4 & 21 & 23 & 56 & $<0.10$ & $<0.22$ & 15 & 0.02 & 0.9 & 0.60 \\
\hline 10.1 & 4.12 & 7.89 & 13.5 & 130 & 332 & 264 & $<0.01$ & 170 & $<0.2$ & 0.06 & 124 & 700 & 136 & 61.3 & 1.79 & 170 & 20.4 & 145 & 663 & 205 & 0.50 & 3.3 & 5 & 22 & 25 & 51 & 0.26 & $<0.22$ & 14 & 0.04 & 0.7 & 0.45 \\
\hline 10.9 & 4.21 & 7.98 & 12.6 & 145 & 347 & 274 & 0.02 & 171 & 0.2 & 0.07 & 124 & 681 & 165 & 61.2 & 2.36 & $<6$ & 4.0 & 183 & 901 & 224 & 0.25 & 3.3 & 4 & 20 & 20 & 40 & $<0.10$ & $<0.22$ & 13 & 0.04 & 1.8 & 0.63 \\
\hline 11.6 & 4.10 & 7.93 & 12.8 & 133 & 338 & 264 & $<0.01$ & 172 & $<0.2$ & 0.06 & 119 & 658 & 166 & 56.0 & 1.96 & $<6$ & 5.4 & 210 & 902 & 253 & 0.27 & 3.3 & 5 & 21 & 22 & 44 & $<0.10$ & 0.28 & 13 & 0.02 & 0.6 & 0.63 \\
\hline 12.5 & 4.12 & 7.92 & 11.9 & 124 & 355 & 264 & 0.68 & 169 & $<0.2$ & 0.06 & 118 & 651 & 181 & 46.7 & 1.95 & 340 & 50.8 & 140 & 943 & 192 & 0.56 & 3.4 & 5 & 23 & 21 & 38 & 0.22 & $<0.22$ & 11 & 0.03 & 8.4 & 0.47 \\
\hline 13.5 & 4.19 & 7.91 & 10.8 & 132 & 364 & 270 & $<0.01$ & 183 & 0.2 & 0.07 & 119 & 645 & 205 & 45.2 & 2.08 & 350 & 16.9 & 221 & 1120 & 254 & 1.09 & 5.8 & 5 & 24 & 21 & 48 & 0.17 & 0.36 & 10 & 0.03 & 2.1 & 0.66 \\
\hline 14.5 & 4.18 & 7.85 & 11.4 & 115 & 366 & 262 & $<0.01$ & 189 & $<0.2$ & 0.06 & 120 & 663 & 203 & 42.2 & 1.83 & 9 & 5.2 & 177 & 1000 & 213 & 0.33 & 3.4 & 5 & 20 & 18 & 39 & 0.27 & $<0.22$ & 8.0 & 0.03 & 0.3 & 0.60 \\
\hline
\end{tabular}




\begin{tabular}{|c|c|c|c|c|c|c|c|c|c|c|c|c|c|c|c|c|c|c|c|c|c|c|c|c|c|c|c|c|c|c|c|c|}
\hline $\begin{array}{r}\text { epth } \\
\text { m }\end{array}$ & $\begin{array}{l}\text { SEC } \\
\text { S/cm }\end{array}$ & $\overline{\mathrm{pH}}$ & $\begin{array}{c}\mathrm{DOC} \\
\mathrm{mg} / \mathrm{l}\end{array}$ & $\begin{array}{r}\mathrm{HCO}_{3} \\
\mathrm{mg} / \mathrm{l}\end{array}$ & $\begin{array}{r}\mathrm{Cl} \\
\mathrm{mg} / \mathrm{l}\end{array}$ & $\begin{array}{r}\mathrm{O}_{3}-\mathrm{N} \\
\mathrm{mg} / \mathrm{l}\end{array}$ & $\begin{array}{r}\mathrm{NH}_{4}-\mathrm{N} \\
\mathrm{mg} / \mathrm{l}\end{array}$ & $\begin{array}{c}\mathrm{SO}_{4} \\
\mathrm{mg} / \mathrm{l}\end{array}$ & $\begin{array}{l}\text { P-tot } \\
\mathrm{mg} / \mathrm{l}\end{array}$ & $\begin{array}{r}\text { P-org } \\
\mathrm{mg} / \mathrm{l}\end{array}$ & $\begin{array}{r}\mathrm{Na} \\
\mathrm{mg} / \mathrm{l}\end{array}$ & $\begin{array}{r}\mathrm{K} \\
\mathrm{mg} / \mathrm{l}\end{array}$ & $\begin{array}{c}\mathrm{Ca} \\
\mathrm{mg} / \mathrm{l}\end{array}$ & $\begin{array}{l}g \\
/ l\end{array}$ & $\begin{array}{r}\mathrm{Si} \\
\mathrm{mg} / \mathrm{l}\end{array}$ & $\begin{array}{r}\text { Fe-tot } \\
\mu \mathrm{g} / \mathrm{l}\end{array}$ & $\begin{array}{r}\mathrm{Al} \\
\mu \mathrm{g} / \mathrm{l}\end{array}$ & $\begin{array}{r}\mathrm{B} \\
\mu \mathrm{g} / \mathrm{l}\end{array}$ & $\begin{array}{r}\mathrm{Sr} \\
\mu \mathrm{g} / \mathrm{l}\end{array}$ & $\begin{array}{r}\mathrm{Ba} \\
\mu \mathrm{g} / \mathrm{l}\end{array}$ & $\begin{array}{r}\mathrm{Cr} \\
\mu \mathrm{g} / \mathrm{l}\end{array}$ & $\begin{array}{c}\mathrm{Mn} \\
\mu \mathrm{g} / \mathrm{l}\end{array}$ & $\begin{array}{r}\mathrm{Co} \\
\mu \mathrm{g} / \mathrm{l}\end{array}$ & $\begin{array}{c}\mathrm{Ni} \\
\mu \mathrm{g} / \mathrm{l}\end{array}$ & $\begin{array}{c}\mathrm{Cu} \\
\mu \mathrm{g} / \mathrm{l}\end{array}$ & $\begin{array}{r}\mathrm{Zn} \\
\mu \mathrm{g} / \mathrm{l}\end{array}$ & $\begin{array}{r}\mathrm{Cd} \\
\mu \mathrm{g} / \mathrm{l}\end{array}$ & $\begin{array}{r}\mathrm{Pb} \\
\mu \mathrm{g} / \mathrm{l}\end{array}$ & $\begin{array}{r}\mathrm{Rb} \\
\mu \mathrm{g} / \mathrm{l}\end{array}$ & $\begin{array}{r}\mathrm{Y} \\
\mu \mathrm{g} / \mathrm{l}\end{array}$ & $\begin{array}{c}\text { Mo } \\
\mu \mathrm{g} / \mathrm{l}\end{array}$ & $\begin{array}{r}\mathrm{U} \\
\mu \mathrm{g} / \mathrm{l}\end{array}$ \\
\hline 0.35 & 33 & 011 & 10 & 36 & .1 & 0.0 & & & .9 & & 21 & 63 & 78 & 13 & 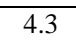 & $<6$ & 20.2 & 336 & ע סט & $4+5$ & 41 & 63 & ? & 10 & 12 & 49 & .10 & 0.22 & 7 & 07 & .2 & \\
\hline 1.1 & 1.02 & .08 & 12.7 & 208 & 43 & 42 & $<0.01$ & 60.7 & 0.5 & 0.47 & 28 & 98 & 95 & 9 & 4.27 & $<6$ & 6.6 & 93 & 214 & 167 & 0.27 & 2.7 & & 7 & 8 & 37 & $<0.10$ & $<0.22$ & 6 & .05 & 4.5 & 0.37 \\
\hline 1.80 & 1.79 & 85 & 7.3 & 154 & 195 & 92 & $<0.01$ & 44.8 & 0.2 & 0.18 & 57 & 133 & 175 & 19 & 3.81 & $<6$ & 4.0 & 138 & 527 & 242 & 0.24 & 3.9 & & 8 & 6 & 32 & $<0.10$ & $<0.22$ & 13 & .03 & 1.6 & 0.31 \\
\hline 2.50 & 2.72 & 7.85 & 5.9 & 139 & 226 & 201 & $<0.01$ & 57.7 & $<0.2$ & 0.09 & 81 & 191 & 267 & 38 & 3.94 & 6 & 4.5 & 151 & 859 & 277 & 0.27 & 5.6 & & 18 & 8 & 50 & $<0.10$ & $<0.22$ & 25 & 0.04 & 1.9 & 0.38 \\
\hline 3.20 & 3.44 & 58 & 5.6 & 135 & 293 & 257 & 0.01 & 53.1 & 0.2 & 0.08 & 101 & 234 & 293 & 42 & 3.06 & $<6$ & 5.2 & 109 & 1027 & 381 & 0.43 & 5.3 & & 18 & 6 & 53 & $<0.10$ & $<0.22$ & 26 & .04 & 0.7 & 0.40 \\
\hline 3.90 & 4.52 & 69 & 10.0 & 134 & 380 & 347 & $<0.01$ & 66.2 & 0.2 & 0.09 & 166 & 418 & 362 & 54 & 3.13 & $<6$ & 9.4 & 116 & 1385 & 368 & 0.43 & 5.8 & 5 & 23 & 10 & 52 & $<0.10$ & $<0.22$ & 38 & 0.04 & 0.6 & 0.44 \\
\hline 4.60 & 4.03 & 92 & 19.7 & 202 & 340 & 254 & 0.15 & 128 & 0.3 & 0.11 & 197 & 578 & 148 & 40 & 3.32 & $<6$ & 6.5 & 401 & 707 & 292 & 0.49 & 11.1 & 5 & 22 & 34 & 81 & 0.88 & 0.31 & 30 & $<0.01$ & 57.7 & 0.56 \\
\hline 5.30 & 5.11 & 05 & 18.3 & 173 & 417 & 354 & $<0.01$ & 152 & 0.3 & 0.08 & 218 & 868 & 145 & 70 & 2.36 & $<6$ & 4.8 & 175 & 690 & 251 & 0.28 & 4.4 & 5 & 19 & 23 & 57 & 0.65 & 0.38 & 50 & 0.04 & 2.0 & 0.64 \\
\hline 5.80 & 5.33 & 27 & 16.6 & 266 & 448 & 330 & $<0.01$ & 214 & 0.2 & 0.08 & 177 & 1050 & 84 & 87 & 2.4 & $<6$ & 3.3 & 173 & 495 & 204 & $<0.22$ & 2.7 & - & 27 & 26 & 40 & 0.25 & 0.56 & 70 & 0.01 & 2.4 & 0.68 \\
\hline 6.20 & 5.59 & 8.04 & 24.4 & 236 & 480 & 339 & $<0.01$ & 260 & $<0.2$ & 0.07 & 174 & 1130 & 85 & 96 & 2.13 & $<6$ & 81.3 & 169 & 574 & 195 & 0.40 & 3.5 & 7 & 41 & 39 & 56 & 0.40 & 1.99 & 55 & 0.03 & 1.3 & 0.78 \\
\hline 6.60 & 5.32 & .08 & 18.6 & 204 & 453 & 333 & 1.52 & 186 & 0.4 & 0.07 & 139 & 1020 & 91 & 68 & 2.35 & $<6$ & 3.1 & 185 & 724 & 181 & 0.24 & 8.5 & 5 & 31 & 32 & 50 & 0.50 & 0.41 & 47 & 0.03 & 34.4 & 0.60 \\
\hline 7.20 & 5.82 & 8.09 & 21.8 & 292 & 476 & 365 & $<0.01$ & 239 & 0.3 & 0.07 & 169 & 1170 & 107 & 95 & 2.72 & $<6$ & 4.6 & 252 & 671 & 327 & 0.33 & 4.4 & 6 & 33 & 31 & 52 & $<0.10$ & 0.36 & 78 & 0.03 & 2.9 & 0.76 \\
\hline 7.70 & 5.75 & 05 & 20.3 & 223 & 480 & 366 & $<0.01$ & 262 & 0.2 & 0.06 & 168 & 30 & 113 & 96 & 2.13 & $<6$ & 11.7 & 171 & 613 & 231 & 0.44 & 2.8 & 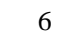 & 31 & 31 & 61 & 0.23 & 0.88 & 46 & 0.02 & 2.2 & 0.78 \\
\hline 8.20 & 5.98 & 8.03 & 25.3 & 235 & 491 & 378 & $<0.01$ & 223 & 0.3 & 0.09 & 160 & 1230 & 70 & 82 & 2.87 & 8 & 7.8 & 261 & 622 & 193 & 1.32 & 5.3 & 8 & 44 & 35 & 39 & 0.25 & 0.38 & 145 & 0.04 & 3.9 & 1.11 \\
\hline 8.70 & 13 & 15 & 33.0 & 409 & 504 & 342 & 0.03 & 306 & 0.6 & 0.32 & 207 & 00 & 55 & 99 & 4.64 & $<6$ & 6.2 & 275 & 447 & 185 & 0.38 & 3.9 & 10 & 67 & 44 & 48 & 0.39 & 0.25 & 20 & 06 & 1.7 & 1.34 \\
\hline 9.00 & 6.06 & 24 & 38.5 & 439 & 521 & 317 & 0.13 & 296 & 0.9 & 0.57 & 211 & 70 & 46 & 87 & 5.17 & 440 & 19.2 & 299 & 272 & 179 & 0.84 & 3.6 & 15 & 188 & 72 & 62 & 1.03 & 28.49 & 110 & 0.06 & 8.6 & 1.86 \\
\hline 9.40 & 5.92 & 11 & 38.0 & 550 & 524 & 285 & $<0.01$ & 291 & 1.1 & 0.78 & 223 & 50 & 45 & 86 & 5.44 & $<6$ & 13.4 & 233 & 388 & 231 & 0.40 & 3.3 & 14 & 96 & 47 & 57 & 0.79 & 1.42 & 244 & 06 & 11.6 & 1.42 \\
\hline 9.70 & 5.78 & .24 & 40.1 & 614 & 539 & 252 & 0.06 & 269 & 0.8 & 0.53 & 225 & 1220 & 41 & 77 & 5.91 & $<6$ & 9.0 & 269 & 293 & 243 & 0.40 & 5.1 & 30 & 189 & 69 & 57 & 0.31 & 2.36 & 177 & 0.08 & 27.6 & 2.09 \\
\hline 10.1 & 5.63 & 21 & 43.2 & 640 & 550 & 238 & $<0.01$ & 246 & 1.7 & 1.04 & 239 & 30 & 39 & 68 & 6.08 & $<6$ & 8.6 & 236 & 326 & 149 & 0.65 & 5.0 & 14 & 158 & 75 & 51 & 0.37 & 0.87 & 67 & .06 & 11.3 & 1.55 \\
\hline 10.4 & 5.61 & 37 & 45.9 & 734 & 567 & 217 & 0.05 & 221 & 0.8 & 0.36 & 254 & 1180 & 35 & 70 & 6.76 & $<6$ & 10.2 & 293 & 393 & 407 & 0.76 & 7.1 & 11 & 93 & 52 & 40 & 1.67 & 1.19 & 145 & 0.03 & 299.5 & 1.45 \\
\hline 10.8 & 5.22 & 35 & 43.6 & 836 & 573 & 147 & $<0.01$ & 191 & 0.8 & 0.42 & 192 & 10 & 28 & 48 & 3.94 & 260 & 31.1 & 266 & 303 & 365 & 1.18 & 17.7 & 21 & 128 & 21 & 115 & 0.46 & 2.55 & 322 & 16 & 4.9 & 2.17 \\
\hline 11.1 & 5.17 & 8.24 & 47.7 & 758 & 558 & 168 & $<0.01$ & 209 & 1 & 0.54 & 240 & 1080 & 33 & 57 & 4.96 & $<6$ & 4.5 & 197 & 275 & 184 & $<0.22$ & 8.4 & 16 & 96 & 44 & 72 & 0.60 & 0.71 & 187 & 0.03 & 7.2 & 1.45 \\
\hline 11.5 & 2 & 34 & 43.1 & 825 & 597 & 0 & $<0$ & 279 & 0.7 & 8 & 210 & 50 & 23 & 50 & 3.61 & $<6$ & 11.9 & 166 & 280 & 134 & 30 & 2.7 & 10 & 74 & 38 & 45 & 0.13 & 0.47 & 190 & 03 & 0.7 & 1.00 \\
\hline 11.8 & 4.76 & 29 & 39.7 & 628 & 624 & .0 & $<0.01$ & 265 & 0.6 & 0.12 & 174 & 70 & 20 & 34 & 2.58 & 87 & 7.9 & 178 & 201 & 133 & 0.90 & 1.5 & 8 & 119 & 47 & 39 & $<0.40$ & 0.87 & 70 & .06 & 6.4 & 1.28 \\
\hline 12.2 & 5 & 32 & 5 & 1020 & 543 & & & 205 & 3. & 2. & 249 & 0 & 34 & 52 & 7.31 & 27 & 5.2 & 201 & 155 & 238 & 0.50 & 4.1 & 20 & 118 & 52 & 42 & $<0.40$ & 1.42 & 172 & 02 & 41.0 & 2.45 \\
\hline 12.6 & 5.06 & 41 & 67.7 & 1070 & 560 & 0 & .4 & 315 & 0.8 & 0.25 & 248 & 60 & 21 & 52 & 3.85 & $<6$ & 7.6 & 217 & 184 & 240 & 0.70 & 2.4 & 16 & 314 & 72 & 66 & $<0.40$ & 1.24 & 128 & 0.05 & 14.5 & 2.21 \\
\hline 12.9 & 4.68 & 1 & 45.0 & 0 & 586 & & 8.0 & 326 & 1 & 0.14 & 210 & 0 & 30 & 35 & 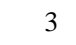 & 340 & 4.7 & 178 & 241 & 140 & 0.23 & 4.5 & 18 & 87 & 48 & 35 & 0.60 & 0.47 & 175 & .03 & 12.3 & 1.48 \\
\hline 13.3 & 4.73 & 38 & 41.4 & 614 & 592 & 7.0 & 0. & 306 & 0.8 & 0.28 & 203 & 964 & 46 & 42 & 3.35 & 330 & 13.8 & 216 & 311 & 137 & 0.30 & 3.9 & 10 & 108 & 52 & 42 & $<0.10$ & 0.57 & 73 & 0.05 & 7.3 & 1.49 \\
\hline 13.6 & 4.7 & 36 & 51.4 & 642 & 597 & 0 & 6 & 301 & $0 . \varepsilon$ & 0.15 & 218 & 1020 & 16 & 40 & 4.7 & $<6$ & 7.0 & 200 & 134 & 191 & 0.58 & 1.7 & 15 & 182 & 56 & 39 & $<0.40$ & 0.65 & 128 & .08 & 12.8 & 2.55 \\
\hline 14.0 & 4.77 & 38 & 55.0 & 743 & 594 & 74.0 & $<0.01$ & 291 & 0.7 & 0.28 & 217 & 1020 & 15 & 43 & 4.86 & $<6$ & 9.0 & 225 & 138 & 196 & 0.59 & 1.7 & 15 & 193 & 55 & 42 & $<0.40$ & 0.94 & 137 & 0.04 & 11.5 & 2.97 \\
\hline 14.3 & 4.57 & 36 & 65.5 & 1010 & 560 & 44.8 & 10.3 & 183 & 3.3 & 2.35 & 202 & 927 & 24 & 44 & 4.69 & 58 & 4.9 & 167 & 156 & 230 & 0.42 & 3.0 & 17 & 123 & 48 & 33 & $<0.40$ & 0.54 & 145 & .02 & 49.5 & 2.38 \\
\hline 14.7 & 3.83 & 8.21 & 23.1 & 337 & 503 & 10 & 14.1 & 122 & 1.3 & 0.33 & 142 & 757 & 23 & 15 & 2.16 & 10 & 4.1 & 169 & 213 & 190 & 0.22 & 2.7 & 19 & 93 & 36 & 41 & 0.22 & 0.75 & 135 & 0.02 & 9.7 & 1.27 \\
\hline 15.0 & 96 & 8.4 & 67.0 & 890 & 586 & 19.6 & 57 & 257 & 4.3 & 0.59 & 219 & 1150 & 18 & 60 & 6.4 & 8 & 6.2 & 199 & 103 & 238 & 0.77 & 2.5 & 21 & 92 & 45 & 44 & $<0.40$ & 1.09 & 194 & .04 & 15.5 & 2.70 \\
\hline 15.38 & 5.03 & 45 & 74 & 1240 & 600 & 25.0 & 8 & 265 & 1.9 & 1.01 & 233 & 10 & 10 & 54 & 7.05 & 26 & 7.3 & 209 & 72.0 & 199 & 0.44 & 0.9 & 27 & 148 & 80 & 40 & $<0.40$ & 0.89 & 181 & 0.05 & 8.2 & 4.39 \\
\hline 15.73 & 4.93 & 35 & 70.0 & 1090 & 605 & 53.0 & & 166 & 1 & 0.46 & 173 & 00 & 13 & 50 & 4.27 & 56 & 8.0 & 165 & 124 & 164 & 0.57 & 2.4 & 25 & 248 & 72 & 54 & $<0.40$ & 0.77 & 139 & .04 & 20.7 & 2.54 \\
\hline 16.08 & 4.75 & 42 & 68.2 & 1000 & 582 & 53.0 & $<0.01$ & 199 & 1.5 & 0.91 & 205 & 1050 & 12 & 59 & 4.42 & $<6$ & 4.5 & 170 & 100 & 199 & 0.46 & 2.2 & 16 & 257 & 72 & 42 & $<0.40$ & 0.84 & 135 & 0.06 & 11.3 & 2.55 \\
\hline 16.44 & 4.74 & 38 & 57.7 & 1020 & 561 & 64. & & 207 & 1.2 & 0.56 & 211 & 30 & 24 & 52 & 7.79 & 24 & 6.6 & 271 & 183 & 197 & 0.61 & 3.6 & 29 & 186 & 67 & 36 & $<0.40$ & 0.97 & 157 & .02 & 34.7 & 2.36 \\
\hline 16.79 & 4.95 & .31 & 43.9 & 1110 & 587 & 64.0 & $<0.01$ & 222 & 0.8 & 0.20 & 206 & 1090 & 26 & 65 & 5.19 & 99 & 6.5 & 325 & 264 & 204 & 0.42 & 3.0 & 15 & 195 & 54 & 38 & 0.27 & 0.90 & 116 & 0.06 & 5.3 & 1.51 \\
\hline 17.14 & 3.77 & 26 & 40.1 & 716 & 475 & 18.4 & 1.77 & 274 & 0.7 & 0.35 & 155 & 734 & 50 & 39 & 5.38 & 45 & 7.9 & 288 & 325 & 162 & 0.39 & 7.5 & 11 & 98 & 24 & 33 & $<0.10$ & 1.24 & 58 & .01 & 4.5 & 1.06 \\
\hline 17.50 & 3.92 & 8.36 & 35.7 & 648 & 561 & 11.1 & 6.7 & 274 & 0.8 & 0.14 & 188 & 775 & 42 & 29 & 4.78 & $<6$ & 12.8 & 336 & 407 & 141 & 0.52 & 3.1 & 12 & 117 & 43 & 33 & $<0.10$ & 0.83 & 52 & 0.03 & 2.8 & 0.96 \\
\hline 18.03 & 3.19 & 15 & 28.8 & 540 & 416 & 15.4 & 1.44 & 240 & 0.6 & 0.15 & 133 & 595 & 58 & 24 & 4.57 & 3 & 5.4 & 238 & 354 & 127 & 0.64 & 5.1 & 8 & 82 & 27 & 35 & 0.23 & $<0.22$ & 43 & 0.03 & 4.6 & 0.91 \\
\hline
\end{tabular}


Table 4 Mean concentrations of gases found in the unsaturated zone atmosphere of the Chalk (Data from Darling et al., 1997)

\begin{tabular}{|c|c|c|c|c|c|c|}
\hline & $\mathrm{N}_{2}$ & $\begin{array}{c}\mathrm{O}_{2} \\
\text { volume \% }\end{array}$ & $\underline{\mathrm{CO}_{2}}$ & $\begin{array}{r}\mathrm{CH}_{4} \\
\text { ppmv }\end{array}$ & $\begin{array}{r}\mathrm{N}_{2} \mathrm{O} \\
\text { ppmv }\end{array}$ & $\mathrm{N}_{2} / \mathrm{Ar}$ \\
\hline Chalk & 77.69 & 19.49 & 1.52 & $<0.1$ & 4.24 & 83.9 \\
\hline Atmospheric & 78.08 & 20.95 & 0.035 & 1.8 & 0.3 & 83.6 \\
\hline
\end{tabular}

